Historic, Archive Document

Do not assume content reflects current scientific knowledge, policies, or practices. 



\section{Perfection NuRSERIES}

1926-1927

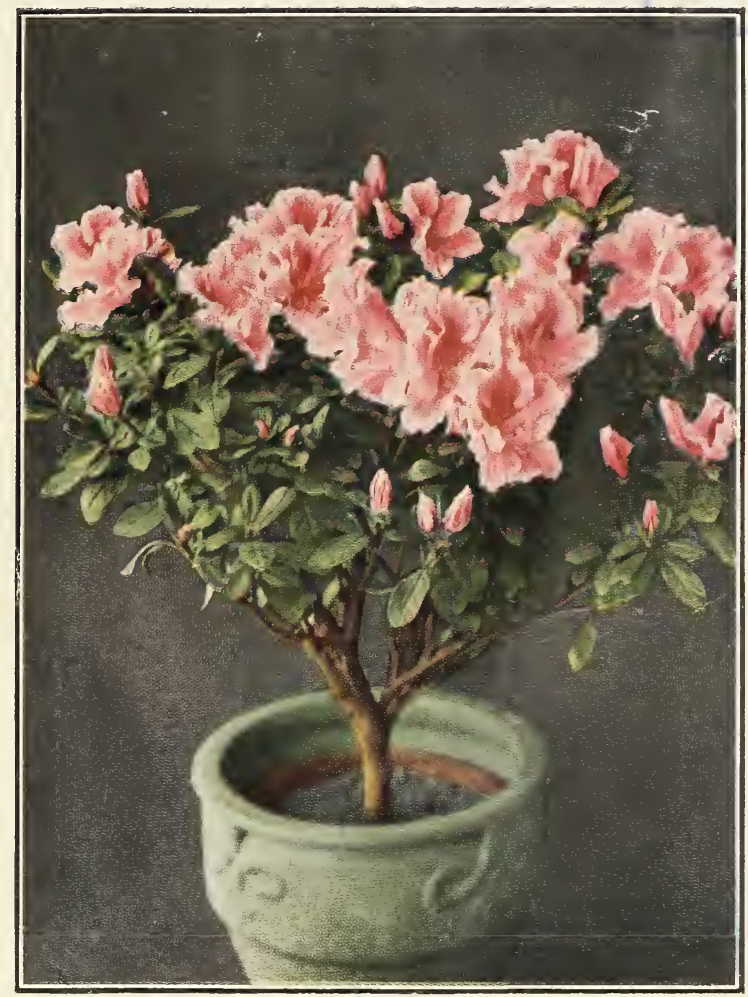

Azalea.

Growers of

High-Grade Nursery Stock

FOLEY, ALABAMA 


\section{Terms of Business}

\section{Iocation-Ofice and Nurseries at Foley, Baldwin County, Alabama, on the $\mathbf{I}$. and $\mathbf{N}$. Railroad.}

INVITATIONS TO VISITORS.-We take pleasure in showing our stock to persons interested. If notified in time, we will meet visitors at the station on arrival.

APPIYING PRICES.-Five, fifty and five hundred trees of one class, at ten, hundred and thousand rates, respectively, purchaser's selection from varieties of one fruit having a common price. For instance, fifty or more peaches, in one or more varieties, would come at the hundred rate, and five hundred or more at the thousand rate. The foregoing does not apply to badly assorted orders, or to long lists made up of a few each of many varieties.

TERMS.-Cash with order, if for immediate shipment. Orders for trees to be held for some weeks after the shipping season opens should also be accompanied by full payment. On orders booked in advance of shipping season, 25 per cent. down, with the balance due when the shipping season opens. We do not care to ship C. O. D.

REMITTANCES.-To secure safety and prompt acceptance, remittances should be made by Bank Draft, Express or Post-Office Money Order, Registered Letter, Prepaid Express, or Certified Check.

METHOD OF SHIPMENT.-Shipping directions should be plainly written, and we urge our customers, in all cases, to use our order sheets. We shall be pleased to forward additional ones upon application. Kindly indicate whether shipment is to be made by freight, express or mail. When method of shipment is left to us, or when no directions are given, we will ship according to our best judgment, by such means as we believe to be in the best interests of our customers.

TRANSPORTATION AT PURCIASER'S RISK AND EXPENSE.-All transportation charges are to be paid by purchaser, and our responsibility ceases upon delivery to forwarding companies. Claims for losses or damages must be made upon the latter. We will, however, start a tracer for delayed shipments, if notified, and use every means at our command to secure prompt delivery, or recovery in case of damage or loss.

SHIPPING BY PARCEL POST.-In ordering trees or plants for shipment by Parcel Post, add 25 per cent to the list price, to cover cost of packing and postage.

TIMEF OF SEIPIERNT.-Unless instructed otherwise, orders received during: the shipping season will be forwarded as soon after their receipt as possible, and orders booked in advance will be shipped as soon as may be after the shipping season opens.

SHIPPING AND PLANYING SEASON.-November to March for all trees and shrubs grown in the open field. Balled and pot-grown plants may be shipped at any time. Shipments from March to November should go by express or post. Prices in this catalogue cover the shipping season of 1926 and 1927 ending first of May, 1927.

SEIECTING VARIETIES.-Suited to locality is of the first importance, and can often be more advantageously done by ourselves than by purchaser. We are always glad to aid our customers in their selection, when so desired, and will, upon request, cheerfully furnish additional information in regard to the adaptability or desirability of particular varieties.

SUBSTITUTION.-It is our desire to furnish stocik exactly as ordered. On orders for commercial planting, substitution of varieties will not be made without permission from customer. On small orders, items which we are unable to supply will be omitted unless we are instructed to substitute.

\section{Printed Iabels attached with wire to everything sent out.}

WE GUARANTEE all stocks sent out to be well rooted, well grown, true to name, properly packed, and shipped according to instructions. Our liability under the foregoing guaranty is limited in amount to the original price received.

CLAIMS.-If, by any possibility, errors should occur they will be promptly rectified, if claim is made within five days after the receipt of the goods.

H. L. WINDBIGLER,

Secretary-Treasurer. 


\section{To Our Friends and Customers}

W

E ARE proud to present our 1926-1927 Catalogue, the largest and best we have ever sent out.

During our 1926 shipping season we filled more orders and shipped more plants than we ever had in any one season. This season we are now offering a larger and more complete line of Nursery Stock than ever before. All our stock must conform to the same high standard we have maintained in grading our plants in the past, and we invite your consideration of our new offerings.

It has been our constant endeavor ta build our reputation on Square Dealing and Quality Plants at Reasonable Prices. We believe in Square Dealing not only because it pays in dollars and cents, but it is the only foundation upon which a lasting and satisfactory business can be built. The many letters received from our customers each year praising our plants and business methods, testify that we are building upon this firm foundation. We pledge ourselves to a continuance of this policy.

Our soil here is peculiarly adapted to plant growth, and practically all kinds of plants are grown here to a perfection that is seldom attained in other sections of the country. Plants grown on this soil develop a wonderful root system and possess the stamina and hardiness to withstand transfer to other soils and climatic conditions. That is why we are able to furnish plants equal to any, and superior to many offered at much higher prices.

In writing this Catalogue we have endeavored to give clear, concise descriptions of varieties as we found them, carefully avoiding exaggeration or painting of extravagant pictures to attract attention. When you order from us you know that everything will be as represented. Furthermore, we live at the Nursery and are actively engaged in the business. Every order receives personal attention both in the office and the packing house.

While we urge the policy of early ordering, we wish to especially emphasize it this year, as the demand will be heavy and supply limited in some lines.

We hope to receive your orders again this season, and with best wishes for a prosperous 1927, we remain,

Very truly yours,

\section{PERFECTION NURSERIES,}

\section{H. L. WINDBIGLER, Sec'y-Treas.}

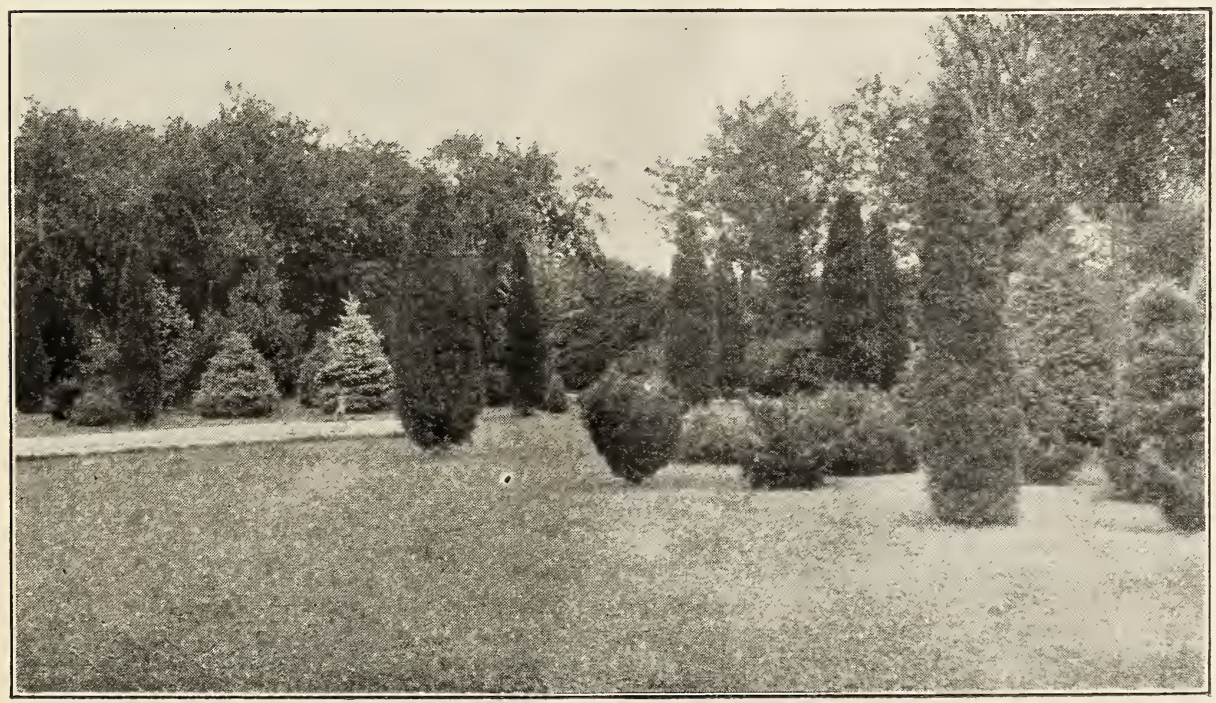




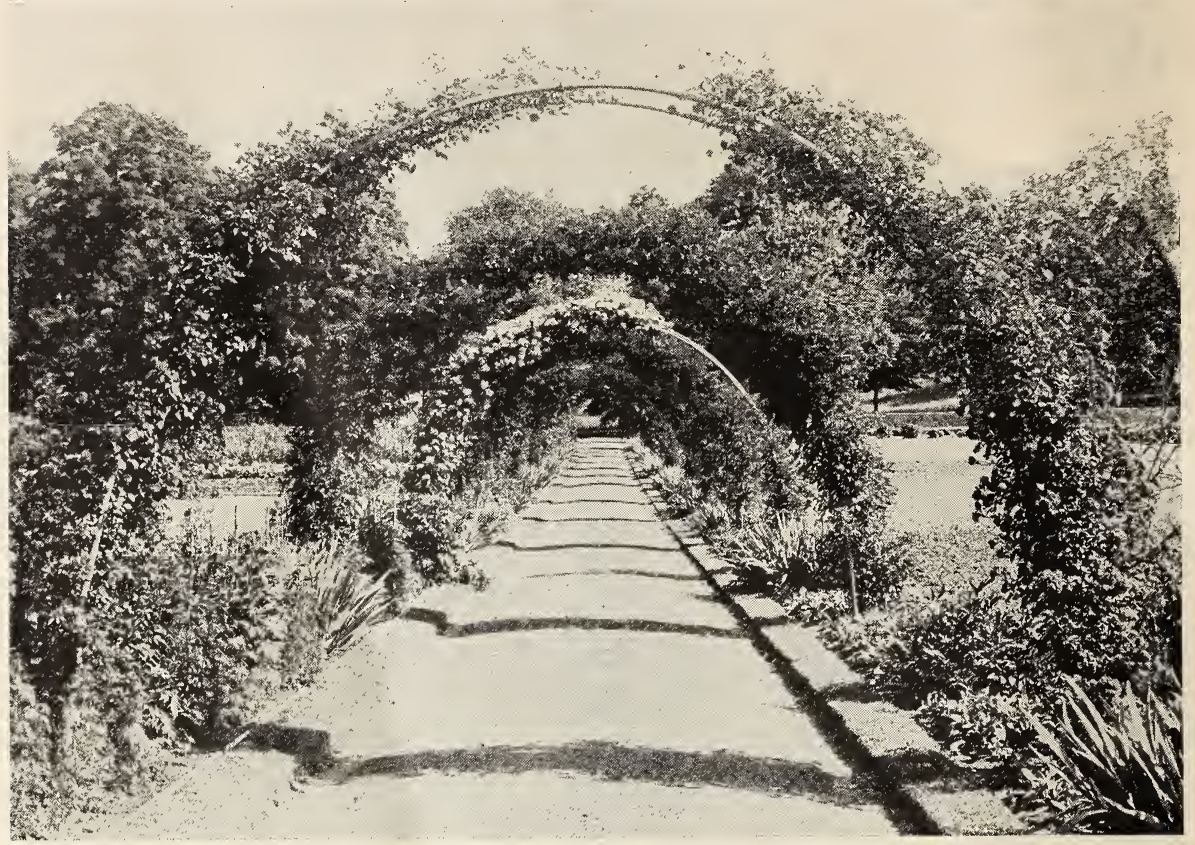

\section{Beautify Your Home With Roses}

The Queen of all flowers, in their beauty can be yours, in all their colors. In the past season we delivered these beautiful flowers all through the Southland. Our Roses grow to perfection, and will bloom the first season; their beautiful blooms will, like incense, prove a benediction of gladness and contentment to you, your family and your friends. We ship anywhere in the U. S. A. proper, and guarantee safe arrival.

Plant Roses-plant lots of them. Buy direct-the best grown Rose Plants in the Southland. Our prices give no idea of the value.

We will furnish specimen plants of any variety we grow at $75 \mathrm{c}$ each.

\section{Roses De Luxe}

\section{YELLOW AND SALMON ROSES}

Mme. Francisca Kruger. (T. Bush.) A very free bloomer, copper-yellow, shaded pink on the outer petals. A fine rose, a continuous bloomer. 50c each.

Sunburst. (H. T. Bush.) One of the finest yellow roses, in color coppery yellow with golden orange in deeper shades; immense buds, long and pointed on stout stems. A magnificent bush rose. $70 \mathrm{c}$ each.

Madam Butterfly. (H. T. Bush.) A free bloomer, with beautiful buds of Indian ochre with yellow at the base, and intermediate tones of clear brilliant shades of coral, opening into semi-double flowers. $50 \mathrm{c}$ each.
Los Angeles. (H. T. Bush.) It is in the class of our very best Roses, grows anywhere, produces a continuous succession of flowers of luminous flamed pink, with translucent gold at the base of the petals. $50 \mathrm{c}$ each.

Mary Wallace. (H. W. Climber.) A new Rose (by Dr. Van Fleet; introduced by the American Rose Society in 1924). Large, very bright pink flowers illumined with shining gold; cup shaped, moderately fragrant. Plant 10 to 15 feet high, and has superb foliage. $70 \mathrm{c}$ each.

President Wilson. (H. T. Bush.) A beautiful Rose, fine buds, pink with a shade of salmon. At its very best in open flowers, has proven to be a showy and dependable garden rose. $50 \mathrm{c}$ each. 


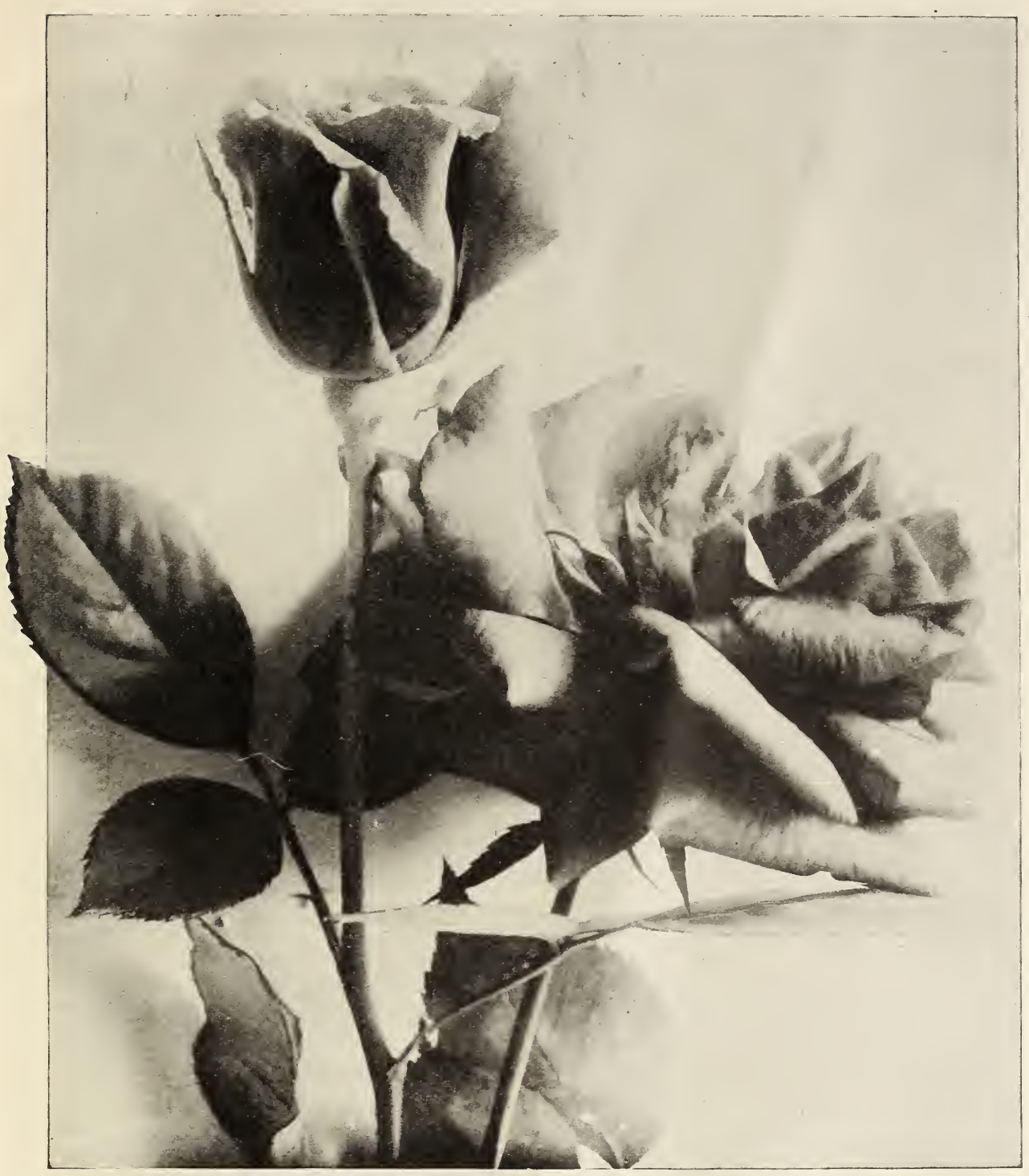

Sunturst.

Marechal Niel. (N. Climber.) The most famous and widely known rose grown in the South today. The flowers are a wonderful shade of clear yellow, and need no further introduction. $50 \mathrm{c}$ each.

Jennette Heller. (T. Bush.) Grows anywhere, perfectly hardy, always in bloom, a beautiful blending of shell pink in the center, shading off to a rosy blush and pale yellow; buds long, pointed and of immense size. $70 \mathrm{c}$ each.

\section{WHITE ROSES}

Kaiserin Augusta Victoria. (T. Bush.) This is one of the most popular of the white roses, owing to its continuous blooming, pointed buds; the large double flowers are glorious in their perfection. 50c each.

Frau Karl Druschki. (H. P. Bush.) Sometimes called the White American Beauty. Buds fine and large, usually pure white. but sometimes with a slight shading of pink on the outer petals. The open flow- 


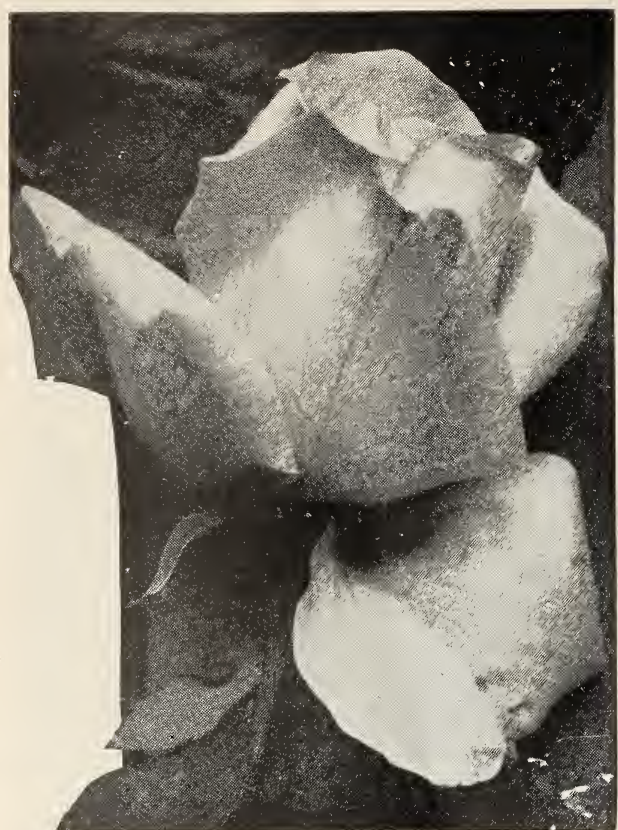

Los Angeles

ers are of great size and the cluster of deep yellow stamens adds a touch of color at the center. A heavy growing rose and extremely hardy. 50c each.

Maman Cochet. (T. Bush.) Of the same habits, size of bloom and delicate fragrance as the Pink Cochet, but of pearly white shading to a most delicate pink that it is easily ranked as one of the best roses. $50 \mathrm{c}$ each.

Devoniensis. (T. Climber.) It is perhaps the strongest growing of the tea roses. The flowers are white, delicately shaded pink. It is a favorite with all who know it. 50c each.

Killarney. (H. T. Bush.) Identical with the Pink Killarney, of which it is an offspring except in color, which is glistening white. One of the most beautiful roses in the bud. $70 \mathrm{c}$ each.

Margaret Miller. (T. Bush.) S i 1 ver white, with delicate shaded center; vigorous grower, a constant bloomer. A rose well liked. $70 \mathrm{c}$ each.

\section{RED ROSES}

Etoile De France. (H. T. Bush.) Lovely shade of clear velvety crimson. Fine form, buds borne on strong stiff stems; good grower and very heavy bloomer; one of the best; medium spreading growth. $50 \mathrm{c}$ each.

American Beauty. (H. W. Climber.) A strong, healthy, vigorous grower, frequently making shoots 10 to 12 feet long; good size flowers for a climber, blooming so freely; color a pleasing rose pink. 50c each.

General Jacqueminot. (H. P. Bush.) A vigorous grower producing flowers of brilliant crimson. This is a favorite. $50 \mathrm{c}$ each.

Reine Marie Henriette. (T. Climber.) It is one of the finest red climbers; the buds are cherry red, large and pointed, and the large open flowers are no less beautiful. A very fine growing rose. $50 \mathrm{c}$ each.

Virginia R. Coxe. (T. Bush.) Also called Gruss an Teplitz, one of the reddest of roses; heavy bloomer and very fragrant. $50 \mathrm{c}$ each.

Red Radiance. (H. T. Bush.) Vigorous grower, very heavy bloomer, fragrant, long stiff stems; one of the best roses for the South.

\section{PINK ROSES}

Mrs. Chas. Bell. (H. T. Bush.) A vigorous grower and extremely free bloomer. In color it is a shell pink with salmon shading at the base of the petals, the most delicate of pink roses. 70c each.

Pink Radiance. (H. T. Bush.) Finest pink rose we know. The buds are rather rounded, the flowers cup-shaped, a beautiful shape of soft carmine pink. Flowers very large, sweet scented, borne on long stems, superb as a cut flower; a strong growing variety. $50 \mathrm{c}$ each.

Pink Killarney. (H. T. Bush.) A strong sturdy upright grower; the buds are exceedingly long and the flowers immense in size; a deep brilliant, sparkling shell pink; a constant bloomer. $70 \mathrm{c}$ each.

Maman Cochet. (T. Bush.) Rose color, shading to a slivery hue. A splendid rose of good habits. Fine for cut flowers; large size and opening into full, double bloom of marked fragrance. $50 \mathrm{c}$ each.

\section{STANDARD Or TREE ROSES}

We have for this season a limited number of Standard Roses to offer, in Radiance, Red Radiance, K. A. Victoria. Each $\$ 2.00$.

\section{SPECIAL OFFER}

One doz. of any of the 50c Roses for $\$ 5.00$ One doz. of any of the 70c Roses for $\$ 7.50$ 


\section{Ornamental Shrubs}

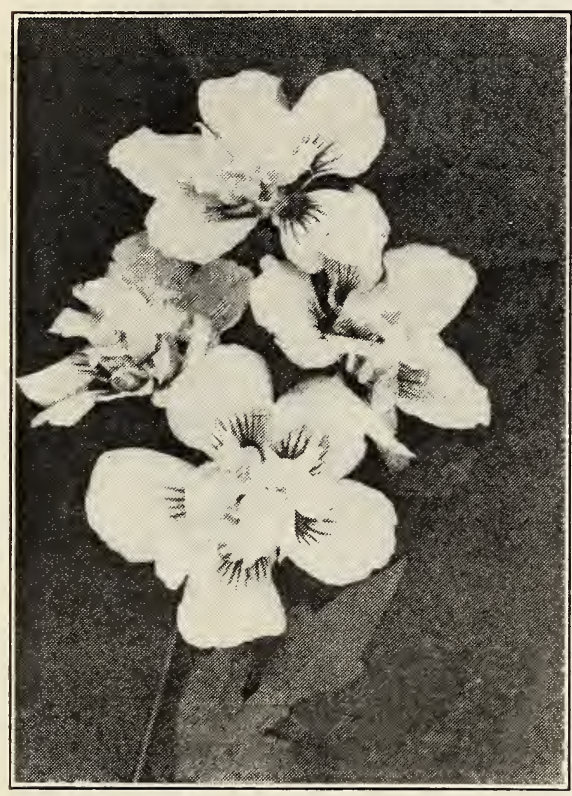

Althea

\section{AZALEA}

What is more beautiful in late winter and early spring than an Azalea, in its many colors? From a distance they look like one mass of flowers. The best soil is one with an abundance of leaf mold, peat and sand. Azaleas will not succeed in limestone soil. We have an extra fine stock of plants to offer this season. Not the tender lath house grown, but strong field grown plants.

Prices-Medium, \$1.00; Large, \$1.25; Specimen, \$1.50.

\section{ALTHEA, Rose of Sharon}

Grows a medium height, blooming the largest part of summer in colors of white, purple, pink, snowy white with scarlet throat. Very gcod for hedges and dividing yards. 25c each; 3 for $65 \mathrm{c}$.

\section{CREPE MYRTLE (Lagerstroemia Indica)}

Favorite flowering shrub of the South; hardy and a heavy bloomer, it paints the landscape in summer months with its brilliant blossoms in tones of crimson, red, white, pink, and other colors. Frequently called the "Lilac of the South." Combinations of Crepe Myrtle colors makes the most exquisite effect. $25 \mathrm{c}$ each; 3 for $65 \mathrm{c}$.
GARDENIA, Cape Jasmine

Old Southern favorite, with glossy leaves and masses of waxy white blossoms; very fragrant. 25c each; 3 for 65c. Specimen Plants, 40c.

\section{PERPETUAL BLOOMING SPIREAS}

Spirea Anthony Waterer. A remarkable free flowering shrub with upright branches, leaves bright green with frequent variegation of yellow. If flowers are cut off as soon as they begin to fade, the plant will bloom the entire season. Very good for low-growing hedge or edging. Color red. 25c each; 3 for 65c. Specimen Plants, 40c.

Spirea Froebeli. A fine free growing sort; rosy colored flowers, produced in large flat heads, upright, and makes a very fine specimen plant; a new variety. 25c each; 3 for 65c. Specimen Plants, 40c.

Spirea Reevsiana. A compact branching shrub, 3 to 4 feet in height, producing a dense mass of pure white flowers; one of the best. 25c each; 3 for 65 c. Specimen Plants, 40c.

Spirea Van Houtti. Branches long and arching; leaves dark green; flowers produced in clusters along the branches. This Spirea is often known as "Bridal Wreath." 25c each; 3 for 65c. Specimen Plants, 40c.

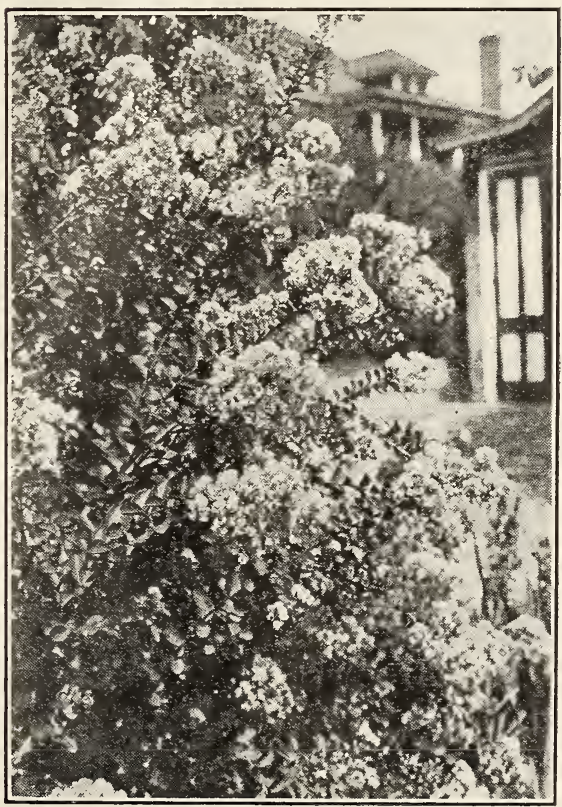

Ciepe Mrytle 


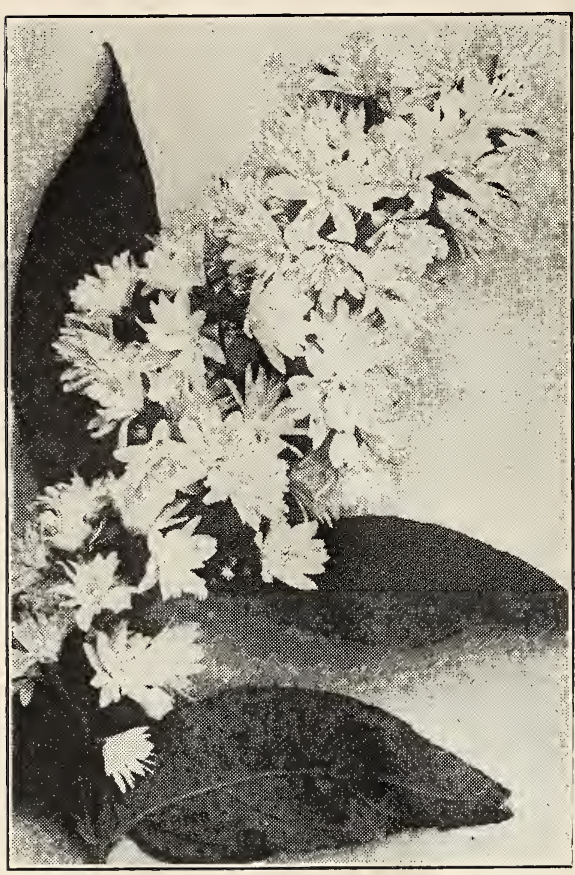

Deutzia, Pride of Rochester

Spirea Billardi alba. A tall growing variety; flowers white, produced in long dense panicles; commences to bloom in May and lasts through the summer. 25c each; 3 for 65c. Specimen Plants, 40c.

Spirea Opulifolia, Bridal Wreath. Vigorous growing variety; white flowers, medium size. $25 \mathrm{c}$ each; 3 for $65 \mathrm{c}$. Specimen Plants, 40c.

\section{HYDRANGEA}

When given a rich, moist soil where they are protected from the sun, there is nothing more attractive than a mass of well-developed specimen Hydrangeas. They are very desirable when grown singly or in tubs. 25c each; 3 for $65 \mathrm{c}$. Specimen Plants, 40c.

\section{LONICERA (Honeysuckle)}

White; a rapid growing evergreen vine; leaves dark green; flowers sweet-scented, white, changing to yellow. Produces a dense covering. 25c each; 3 for $65 \mathrm{c}$.

\section{LONICERA (Marrow Honeysuckle)}

A Japanese variety producing a profusion of white flowers early in April, followed by a mass of bright red fruit in fall. A good growing shrub.
Lonicera Pink. A Japanese variety of medium growth, producing beautiful pink flowers in early April. Very showy.

Lonicera alba. Flowers pure white; blooms in spring, flowers lasting about six weeks. A good variety.

Prices on above varieties $-25 \mathrm{c}$ each; 3 for 65c. Specimen Plants, 40c.

\section{WEIGELA}

A beautiful shrub that blooms in June and July. The flowers are produced in great profusion, almost hiding the foliage. They are very desirable for the border or for grouping.

Eve Rathke. A deep carmine red.

Candida. A very beautiful white bloom.

Variegated. Foliage variegated; pink flowers.

Rosea. Flowers are light pink, compact grower, free bloomer.

Prices on above varieties $-25 \mathrm{c}$ each; 3 for 65 c. Specimen plants, 40 c.

\section{HIBISCUS (Confederate Rose)}

A tall growing shrubby plant, with large angled and toothed leaves. Flowers light pink changing to red; very desirable. $25 \mathrm{c}$ each; 3 for 65 c. Specimen plants, 40 c.

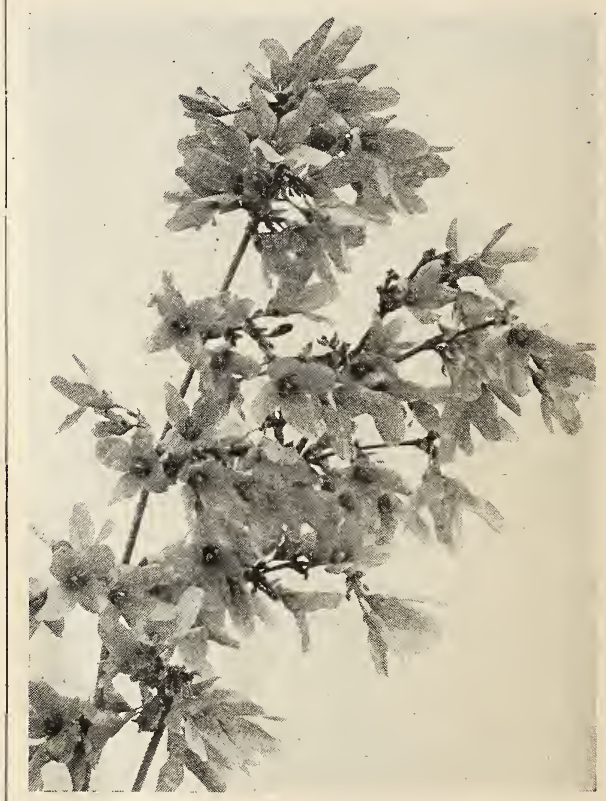

Forsythia. 


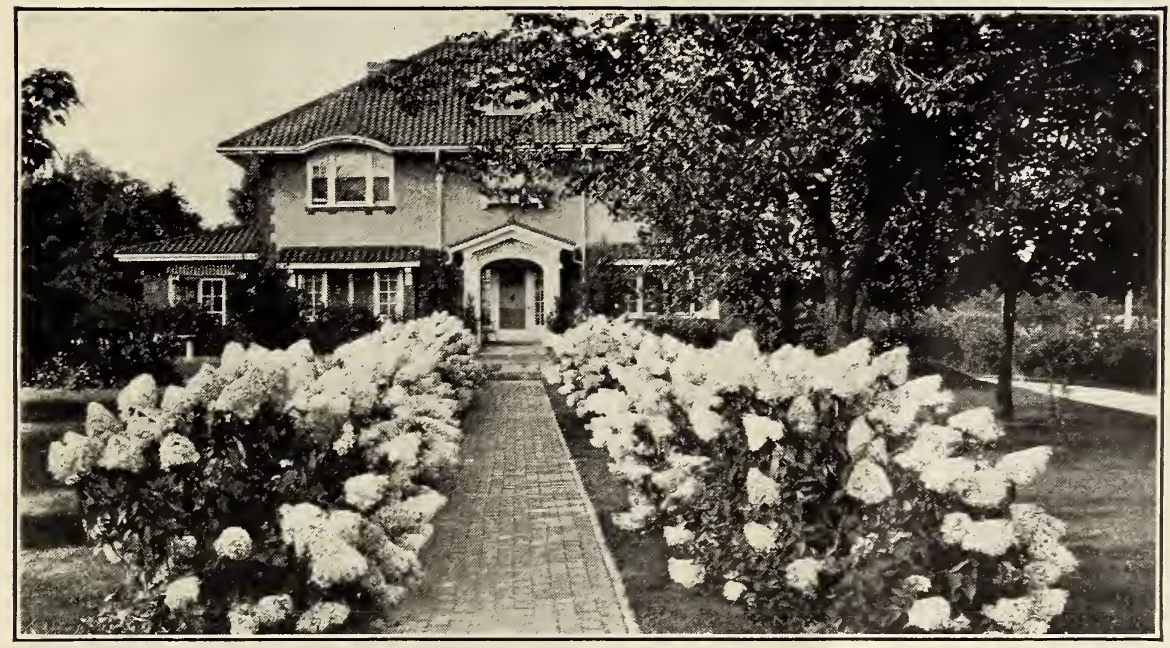

A Beautiful Planting of Hydrangeas

\section{DEUTZIA}

Pride of Rochester. Large, double white flowers tinged with pink; grows to good size specimens. 25c each; 3 for $65 \mathrm{c}$. Specimen plants, 40c.

\section{FORSYTHIA}

Forsythia or Golden Bell. Comes into bloom the first warm days of spring; their

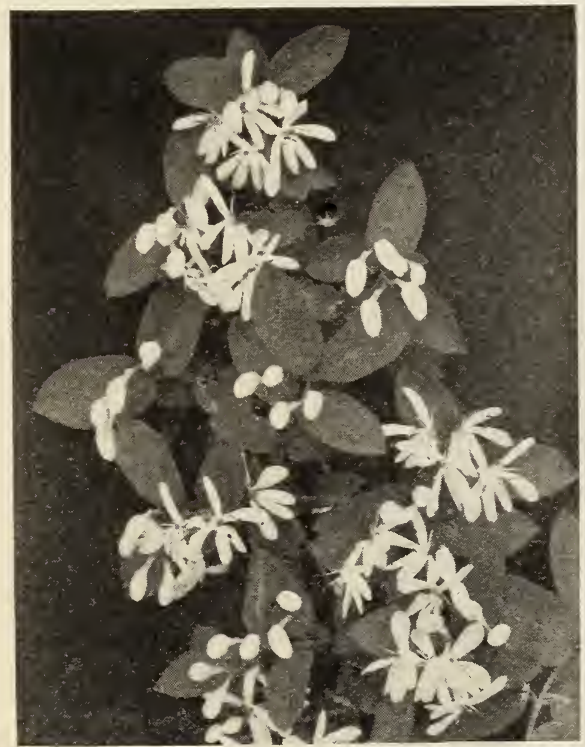

Ionicera (Bush Honeysuckle) masses of bright yellow flowers are borne before the leaves appear. One of the first shrubs to bloom in spring.

Fortunii (Fortune Golden Bell). Of graceful upright habit, this variety is one of the best.

Intermedia. Bright golden yellow flowers on slender, arching branches; foliage a rich glossy green.

Viridissima. A fine variety with leaves and bark a deep green. Flowers deep yellow, blooming little later than the Intermedia.

Prices for the above varieties $-25 \mathrm{c}$ each ; 3 for $65 \mathrm{c}$. Specimen- plants, $40 \mathrm{c}$.

\section{SYMPHORICARPOS}

Coralberry or Indiant Currant. A native shrub growing from New York to Texas, four to six feet tall; purplish red berries all produced in great profusion. They remain upon the plant all winter, making it especially desirable for landscape planting. 25c each; 3 for 65c. Specimen plants, $40 \mathrm{c}$ each.

\section{PHILADELPHUS}

Syringa or Mock Orange. Will be found highly desirable for growing with other shrubs; of strong vigorous growth. Blooms in early spring, flowers of pure white borne Specimen plants, 40c.

in large clusters. 25c each; 3 for $65 \mathrm{c}$. 


\section{Shade and Ornamental Trees}

\section{FLOWERING ALMOND}

During March the double flowering A1mond is covered with masses of beautifully formed and highly colored flowers. This tree is highly recommended for early spring blooming.

We can supply Flowering Almond in either Double White or Pink. 25c each; 3 for $65 \mathrm{c}$.

\section{CORNUS (Dogwood)}

The large white flowering Dogwood, a most effective plant for the lawn. 25c each; 3 for 65 c.

\section{MAGNOLIA}

Magnolia. grandiflora. The grandest broad leaved evergreen tree of the Southern forests. Leaves bright shining above, usually coated with brownish tinge beneath; flowers large, beautiful pure white, lemon scented, produced throughout the spring months.

2 to $3 \mathrm{ft}$., each $\$ .50$

3 to $4 \mathrm{ft}$., each .75

5 to $6 \mathrm{ft}$., each 1.00

Specimens 1.50

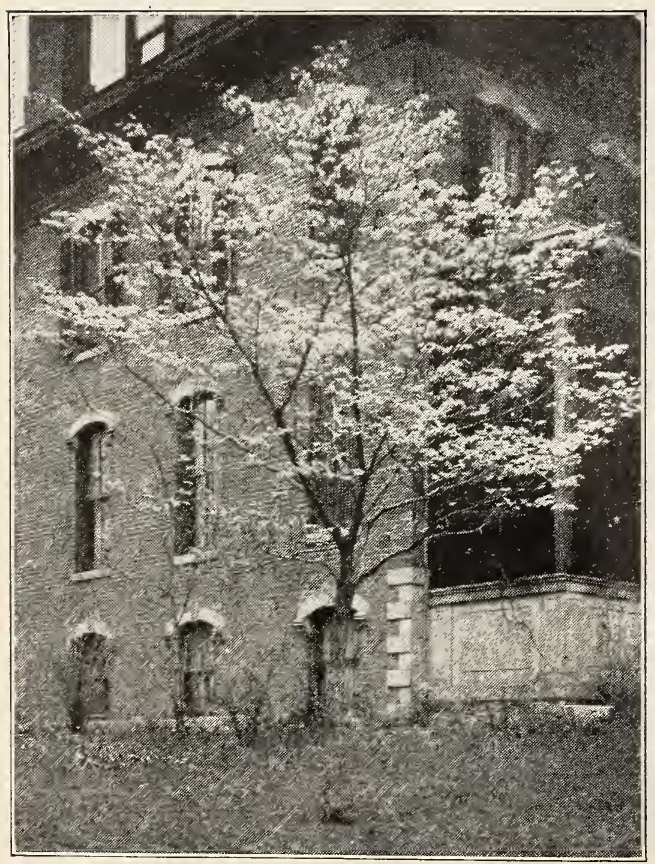

White Flowering Dogwood

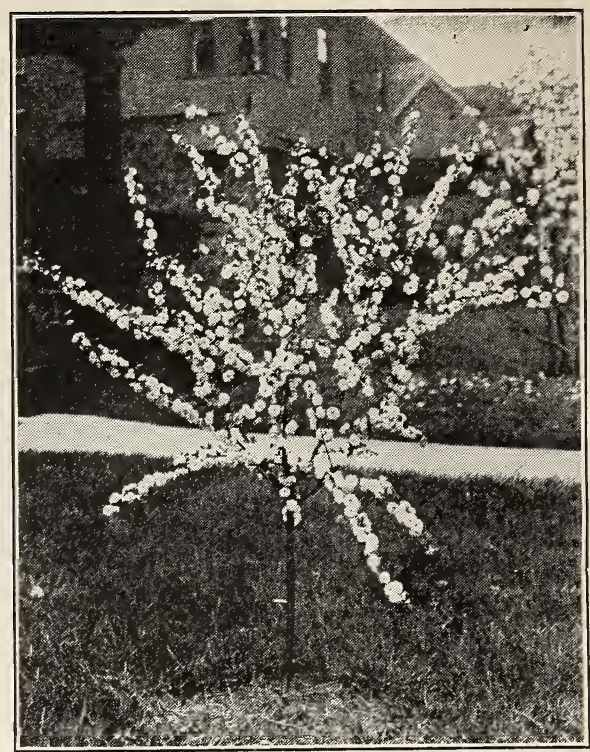

Flowering Almond

TALLOW TREE

A r a pid grower; bright shining leaves that turn to many beautiful colors in autumn; a very desirable shade tree.

$$
\begin{aligned}
& \text { Each. Per } 10
\end{aligned}
$$

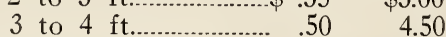

TUNG (Chinese Wood Oil Nut)

This tree is a very rapid grower, and is being "planted extensively in Florida; the oil from the nut being valuable for the manufacture of varnish. You can plant these trees along the lane or around the fences. It does well in Alabama.

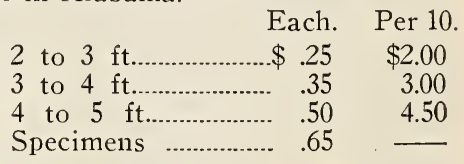

NELIA (China Tree)

Texas Umbrella Tree

A variety of the China Tree. It has a dense, spreading head, resembling a gigantic umbrella. A most desirable tree of rapid growth. Ultimate height 25 feet. $25 \mathrm{c}$ each; 3 for $65 \mathrm{c}$. Specimen plants, $75 \mathrm{c}$. 


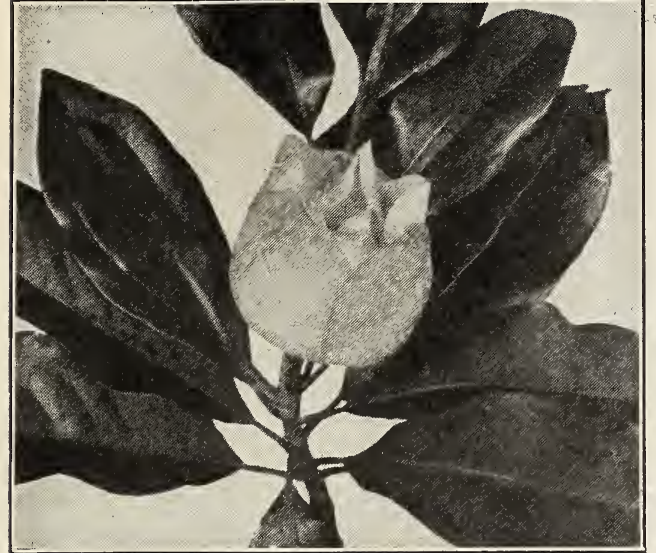

Magnolia Grancliflora

\section{Plant Shrubs}

Shrubs are the most important ornamentals and give quickest results. They are invaluable as specimens; in groups or continuous borders; as screens against objectionable views or to secure privacy; as barriers or windbreaks; for flowering effects, for attractiveness of foliage or fruit. They relieve the harshness where house and lawn meet and the sharpness of corners. They are valued and appreciated more and more, as indicated by a thousand sold now to one a generation ago. They have the greatest range of color and bloom, and occupy the most important space in the grounds - and they give the quickest results. They are especially valued where there is only room for a few trees. The tall shrubs planted as a boundary make an effectual screen, and even on the larger estates an undergrowth of shrubbery is usually planted under the trees along the boundary. Many fine old places have an excellent growth of trees, but lack a proper planting of shrubs. Shrubs are the natural complement of trees, filling in the gap between their branches and the ground, and it is possible to get homelike results from shrubs that it would take years to acquire with trees alone.

\section{Vines and Hedging}

\section{WISTARIA}

This Climbing Shrub with its masses of deep purple and pure white flowers that comes early in the spring makes it a favorite with all. Very hardy, 25c each; 3 for 65c. Specimen plants, $40 \mathrm{c}$.

\section{PRIVET HEDGE}

Amoor River. A densely branched variety of rapid growth, with small evergreen leaves. The best hedge Privet known, and may be pruned in any desired form. Each 10c; 10 for $80 \mathrm{c}$; 100 for $\$ 3.50$.

\section{BERBERIS}

(Thunberg's Barberry) A dwarf shrub from Japan; leaves small, bright green, changing in autumn to be a ut if ul tones of orange, scarlet and crimson; has red berries. A popular plant for massing and for hedges. $25 \mathrm{c}$ each ; 3 for $65 \mathrm{c} ; 12$ for $\$ 2.50$.

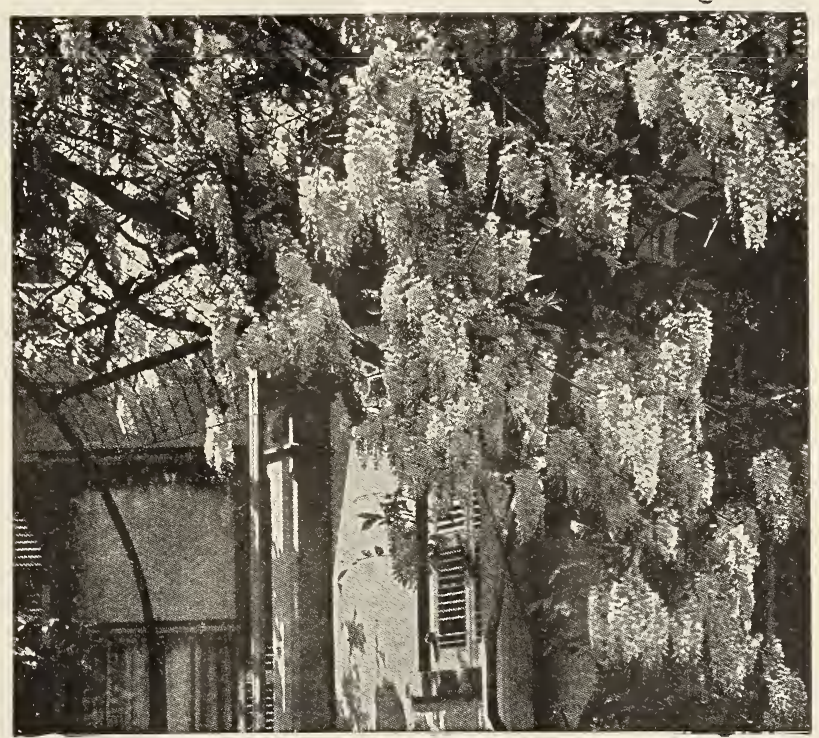

Wisteria Chinensis. 


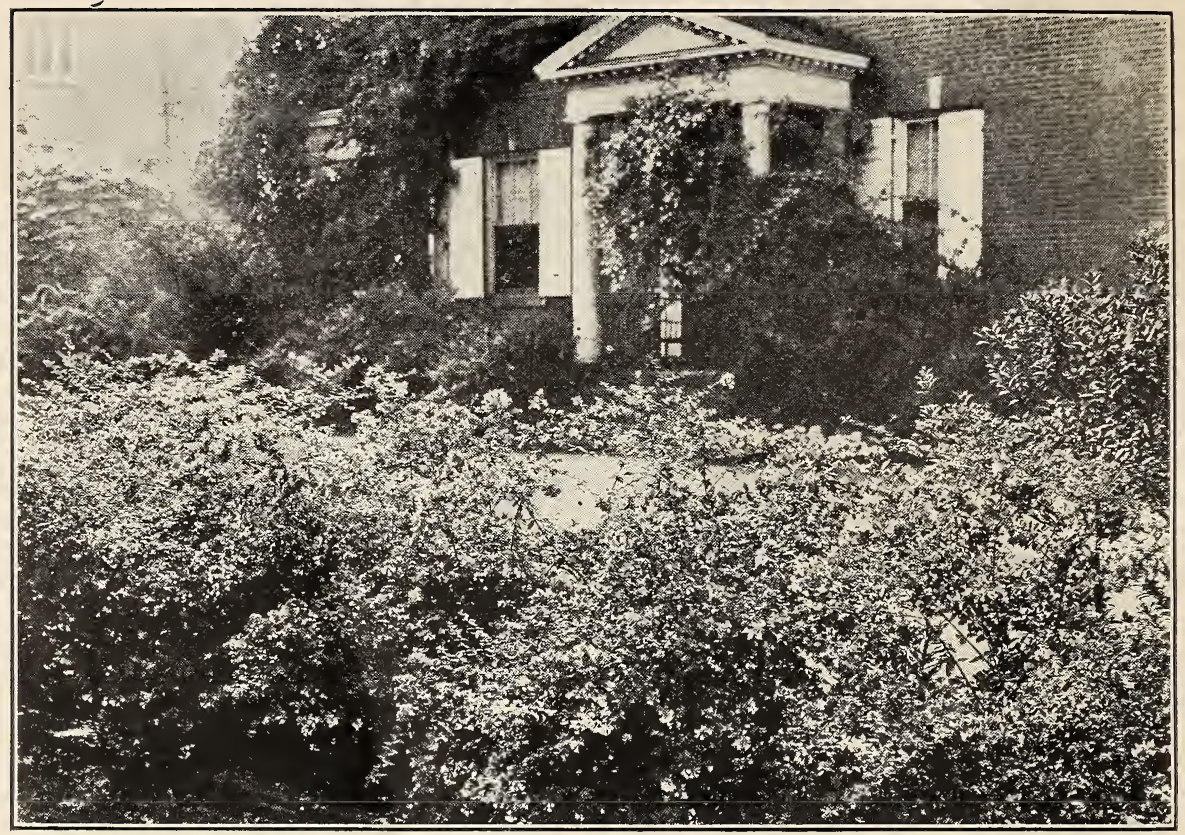

Abelia Grandiflora

\section{Broad-Leaved Evergreens}

\section{LIGUSTRUM LUCIDUM}

A beautiful form of Japanese shrub. Leaves large, thick, ovate, lanceolate, of a very dark shining green; large heads of white flowers produced in May, followed by black berries which are retained thru the winter; very hardy; makes fine single specimen; can be sheared into any form; very desirable.

35c each. Large plants, 50c.

\section{LIGUSTRUM JAPONICUM}

A very handsome broad-leaved variety, with large, dark green leaves; flowers produced in panicles followed with purple berries, which are retained during the winter, giving the plant a very pleasing appearance. This plant can be grown into a small tree; can also be trimmed into pyramidal, standard or to other forms.

$25 \mathrm{c}$ each; 3 for $65 \mathrm{c}$.

\section{ABELIA GRANDIFLORA}

An evergreen shrub with dark green, glossy leaves, turning to bronze in winter. Flowers white, funnel shaped, tinged with pink, delicate sweet scented and borne in clusters from early spring until late autumn. Good as a hedge or single specimen. Does not harbor insect pest.

$\begin{array}{lrrr} & \text { Each. } & 10 . & 100 . \\ 1 \text { year plants................ } & .25 & \$ 2.00 & \$ 18.00 \\ 2 \text { year plants............. } & .40 & 3.50 & 32.00 \\ \text { Specimen plants ....... } & .75 & - & \end{array}$

\section{ILEX (Yaupon)}

Small leaves of a glossy green, bearing immense quantities of berries, turning a bright red in early autumn and remaining until early spring.

Price-25c each; 3 for 65c. Specimen plants, 40c; extra large, 65c.

\section{ILEX (Holly) (American)}

The Christmas Holly. Its bright green leaves and brilliant scarlet berries make it one of our handsomest evergreen shade trees.

Price-2 to $3 \mathrm{ft}$., $50 \mathrm{c}$ each; 3 to $4 \mathrm{ft}$., $75 \mathrm{c}$ each.

\section{OLEANDERS}

In evergreen shrubs this is one of the very best for the South, with its long narrow green leaves and well colored flowers, which make it a great favorite with all. We have fine plants in Double Red and large Single White, of the very best.

Price-25c each; 3 for 65 c. Specimen plants, $40 \mathrm{c}$. 


\section{Coniferous Evergreens}

\section{Biota Orientalis Compacta Rosedale Pyramidal Aurea nan}

Price, each

There are many of our friends who prefer to order the small Evergreens, and grow on for their Specimen Plants and for hedges, and this season we are offering the Pyramidal and Compacta in nice size plants and will make fine Evergreens.

Price-25c each; 3 for 70 c.

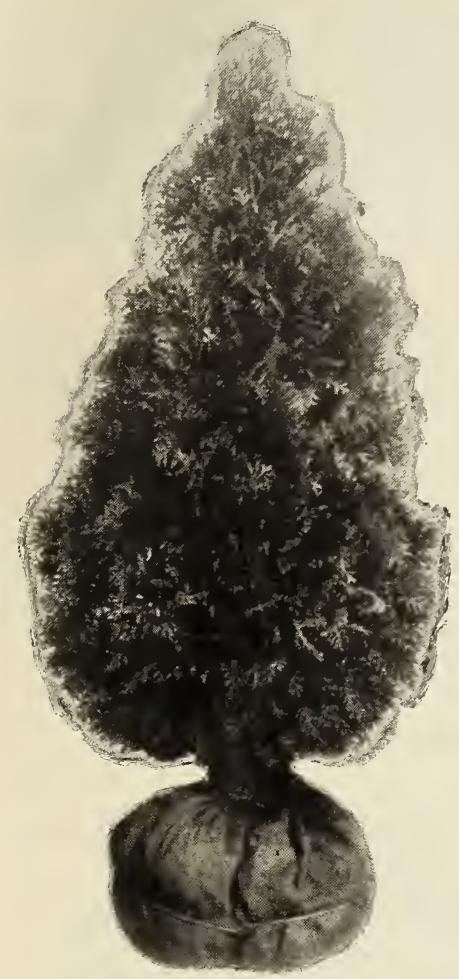

Rosedale Arborvitae
If You Want

an

Up-to-the-

Minute

Home,

Plant

Evergreens,

Which

Not Only

Beautifies

But Increases

the Value of

Your Home

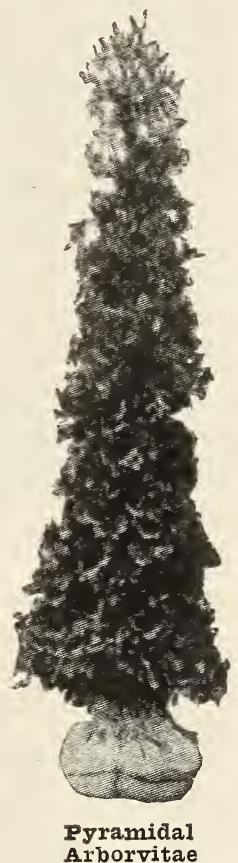

\section{Special Offer}

PORCH BOX, VASE, AND HANGING BASKET PLANT COLLECTION

In the past we have had so many of our friends say, "What shall I put in my porch box?" and our suggestions have been readily accepted, and others ordering, liking the arrangement of plants so well, we are making for this season two collections of plants that we know will please anyone.

Collection No. 1. Twelve plants, all different-our selection from following list: Salvia, Dracena, Wandering Jew, Ostrich Fern, Boston Fern, Vinca, Ivy Geranium, Coleus, Petunia, Begonia, Verbena, Geranium, Canna, Asparagus, Sprengeri, Fancy-leaved Caladium. Price $\$ 1.00$.

Collection No. 2. For box 8 inches wide by 3 feet long-16 plants, our selection from the above list. Price $\$ 1.25$. 


\section{MISCELLANEOUS PLANTS}

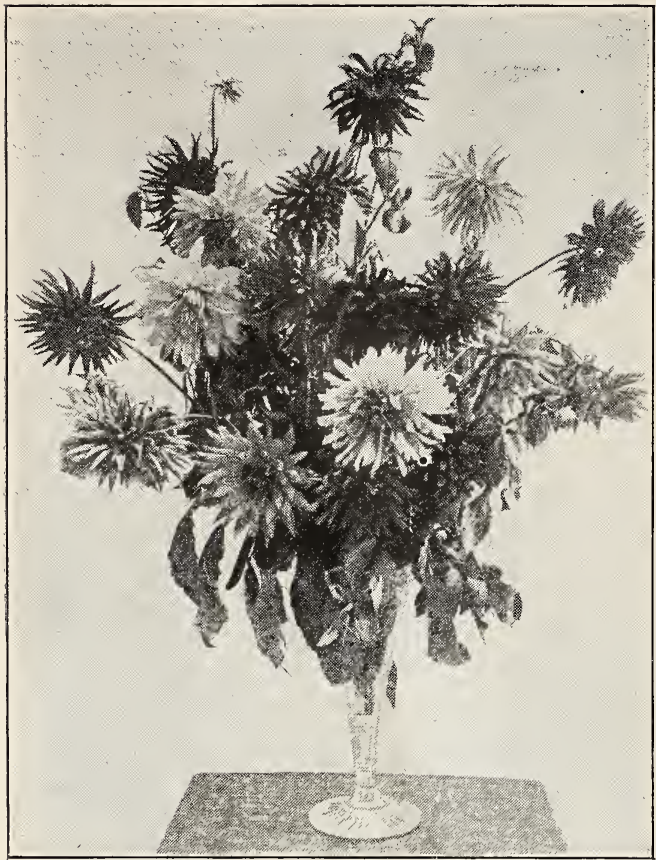

\section{Perfection Hardy Chrysanthemums}

White Chieftain. Pure white beautiful ball shaped flowers. Good in every way.

Golden Chadwick. Beautiful golden yellow, one of the best.

Chadwick Supreme. Wonderful shade of pink, one of the latest in the Chrysanthemum family.

Harvard. Crimson, the best of its color.

Christmas Gold. Rich deep tones of gold, and a favorite in its color.

Lillian Doty. Beautifully formed shell-pink. Extra fine.

Superb Collection of Chrysanthemums. Two each of the above varieties, $\$ 1.25$ postpaid; if ordered separate, $15 \mathrm{c}$ each; $\$ 1.50$ per doz.

Wonder Chrysanthemum Mixture of the old Favorites. This includes colors not in our Superb Collection. 1 doz. $\$ 1.00$, postpaid.

\section{Flowering Begonias}

One of the South's natural plants. It thrives and blooms under all conditions. Six of the following fine plants postpaid for $\$ 1.50$.

Chatelaine Supreme. New everblooming Begonia. Finest bloomer known; low bushy habit and literally covered in a wealth of beautiful Christmas red flowers, with yellow stamens. 30c each; 3 for $80 \mathrm{c}$.

Coralline Lucerne. Wonderful new Begonia bearing immense flower clusters of bright coral red, changing to delicate pink. Every lady who has seen it in bloom has bought one. $25 \mathrm{c}$ each; 3 for $70 \mathrm{c}$.

Alba Picta. Long thick leaves, silvery spotted with pink flowers. 20c each.

Alba Perfecta, or White Rubra. Medium long light green leaves; large trusses of pure white flowers with yellow stamens. 20c each.

Sandersonii. A coral Begonia with scarlet crimson flowers, blooming continually. $25 \mathrm{c}$ each.

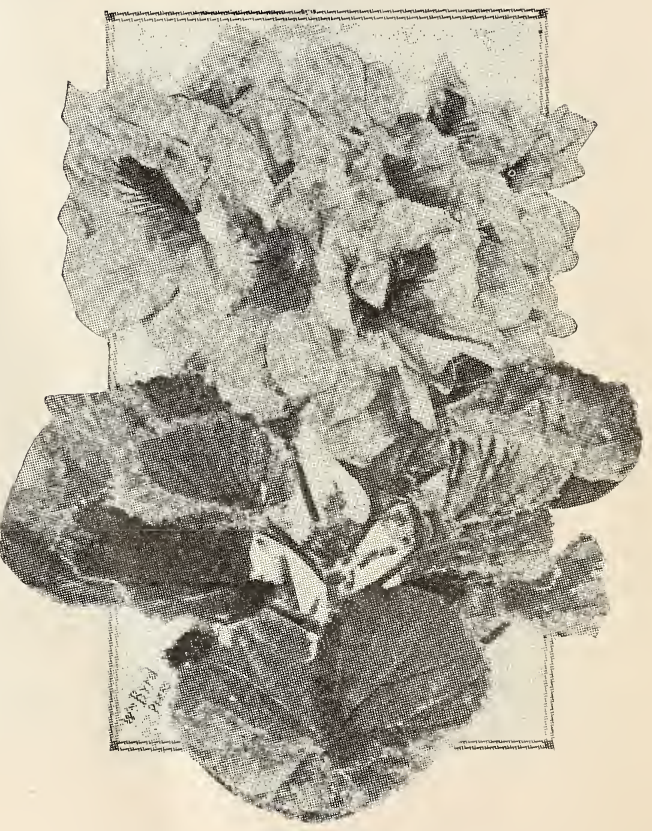

Begonia 


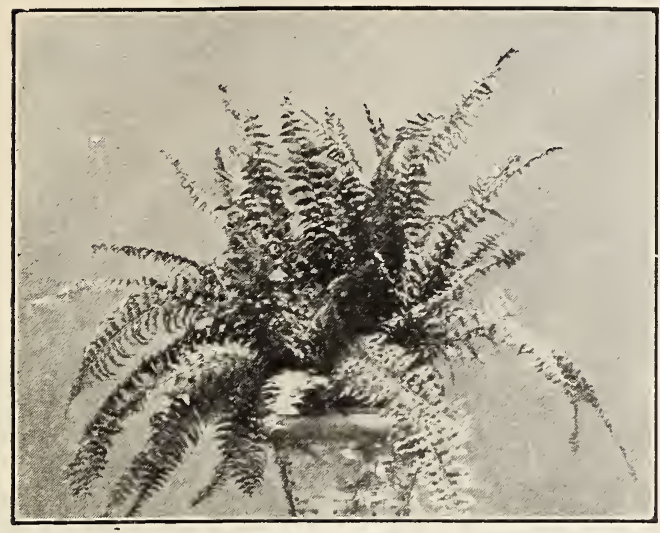

Boston Fern

Feastii or Beetsteak Begonia. Of spreading habit, leaves circular and of extra heavy texture, red underneath, giving the effect of a beefsteak, glossy olive green above. Flowers dainty coral red. Grown as easy as a Geranium. 25c each; 3 for $70 \mathrm{c}$.

Star Begonia. Very large leaves of a rich green with reddish markings, velvety surface, bloom is a magnificent pink borne in spray like clusters lifted quite clear of the foliage. $50 \mathrm{c}$ each; 3 for $\$ 1.25$.

Angel Wings Begonia. A very sturdy grower, with long pointed thin green leaves, drooping, giving them the appearance of angel wings hearing clusters of immense red flowers with red stamen. The best of the large growing Begonias. 35c each: 2 for $65 \mathrm{c}$.

Mammoth Leaved Rex Begonia. The most wonderful Begonia in the world. Mammoth leaves of rich metallic lustre, colors blending from brightest green, glistening silver and orange to beautiful plum hues. Flowers blush-pink. $35 \mathrm{c}$ each; 3 for $\$ 1.00$.

\section{Ferns and Decorative Plants}

No home ought to be without Ferns, which serve as splendid decorative plants in the house, as well as for hanging baskets and porch boxes.

Boston Fern (Nepholepsis). We have some beautiful specimens. The fronds frequently attain a length of five to six feet; graceful drooping habit. It can be used as a house plant or under shade trees in summer. This is a standard and most popular variety. Fine Young Plants, 20c; Medium, 25c; Extra Strong Plants, 75c.

Ostrich Plume (Nepholepsis). It has taken gold medals wherever shown, and is one of the most valuable ferns introduced in many years. The decorative fronds are made up of many leaflets that are finely divided, making it a charming fern. Fine Young Plants, 30c; Specimen Plants, \$1.00.

Roosevelt (Nepholepsis). There is no Fern that will compare with this new and charming variety; it is generally like the Boston Fern but produces many more fronds, making it bushier and more handsome. Its superiority should place it in the hands of every Fern admirer. Fine Young Plants, 25c; Extra Strong ones, 75c.

Big Four Fern (Nepholepsis). Most wonderful new fern with the grace of the Boston, the wavy effect of the Roosevelt, the fluffiness of an ostrich plume, and the uniqueness of a fish tail. Fine Young Plants, 25c; Extra Strong ones, \$1.

Baby's Breath Fern. This is the most delicate of all lace Ferns and really looks like filagree work. It is finer and more ornamental than any of the others. And makes a Table Fern par excellence. Fine Young Plants, 40c.

Feather Fern (Asparagus Sprengeri). A magnificent porch or basket plant in the South. The fronds or leaves grow four to five feet long. When cold weather comes it makes a splendid house plant and will succeed under most adverse conditicns. Fine Young Plants, 20c each.

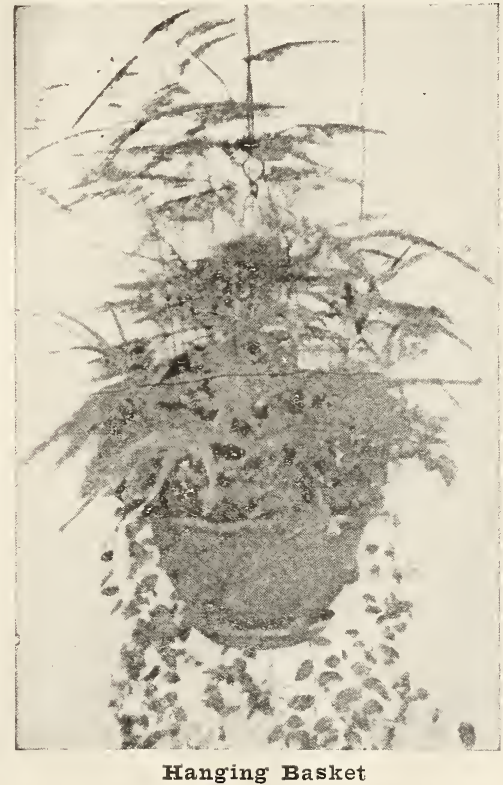




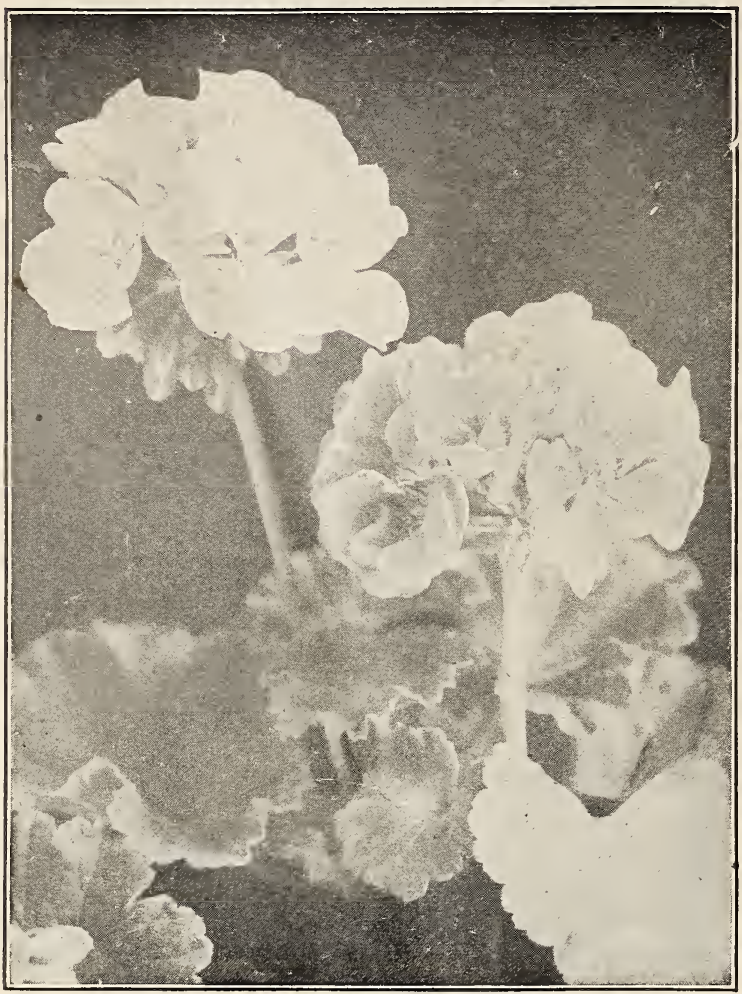

Geranium

\section{Special Offer}

\section{Perfection Mixture}

\section{GLADIOLUS COLLECTION}

Every one wants to have the finest and latest in the Gladiolus Creations. Here in this mixture you will find them, all the colors of the rainbow, this being one of our finest cut flowers. One should make several plantings about four weeks apart in the spring till July 1st, so you may have blooms of these fine flowers all summer long.

Fine blooming size bulbs, $35 \mathrm{c}$ per dozen; 3 doz. for $\$ 1.00$.

FICUS ELASTICA (India Rubber Tree)

This is the common rubber tree grown so much as a decorative house plant. The leaves grow to 12 inches in length, are very dark glossy green, leathery in texture. As a decorative plant it is very easy to culture and has a handsome appearance.

Medium, 50c each; Large, 75c; Extra Large, \$1.00; Specime11, \$1.50.
FERNS-Continued

Lace Fern (Asparagus Plumosus nanus). A tall climbing decorative plant and one of the rarest beauty. Its bright green foliage is extremely fine and plume-like. The fronds grow from six to eight inches in width, and when cut retain their color and shape for weeks. Plants may be grown as pot plants or form a bushy climber, and thrives under practically all conditions; it likes a rich soil. Strong Plants, 20c; Large Plants, 60c.

We ship Pot Plants any time of the year, and will substitute, if out, unless otherwise instructed.

\section{ASPIDISTRA}

A beautiful plant with large, lace leather-like leaves; a rich deep green in color. Unusually decorative and an elegant window or porch plant of the easiest culture. Extra Fine Plants, \$1.00 each.

\section{FOUNTAIN PLANT}

Beautiful plant with slender drooping leaves of $\mathrm{several}$ shades of green with delicate striping of yellow and red. 20c each; 2 for $35 \mathrm{c}$.

\section{EVERLASTING BLOOMER or IMPATIENS}

Sultani. A mass of orange pink flowers. Pink Beauty. Clear rose pink.

Salmon Queen. Light salmon color, a new one. $15 \mathrm{c}$ each; 3 for $40 \mathrm{c}$.

\section{RAINBOW FERN}

All the beautiful colors of the rainbow; leaves of a fine lace-like nature that is admired by all who see it. It is one of the most beautiful of plants; very hardy. 20c each: 2 for 35c.

MOUNTAIN ROSE, sometimes called Maderia, Mexican or Antigonon Vine.

The Mountain Rose with its delicate and graceful growth is no doubt the most lovely of our typical Southern vines. The foliage is of a fresh light green color, and the flowers are a beautiful rose pink borne in racemes reaching to a length of two feet or more. Unsurpassed for covering porches, fences, old tree stumps. Blooms in August, September and October. From a distance it resembles a Rambler rose, hence the nickname. Tubers, 25c each! 3 for $70 \mathrm{c}$. 


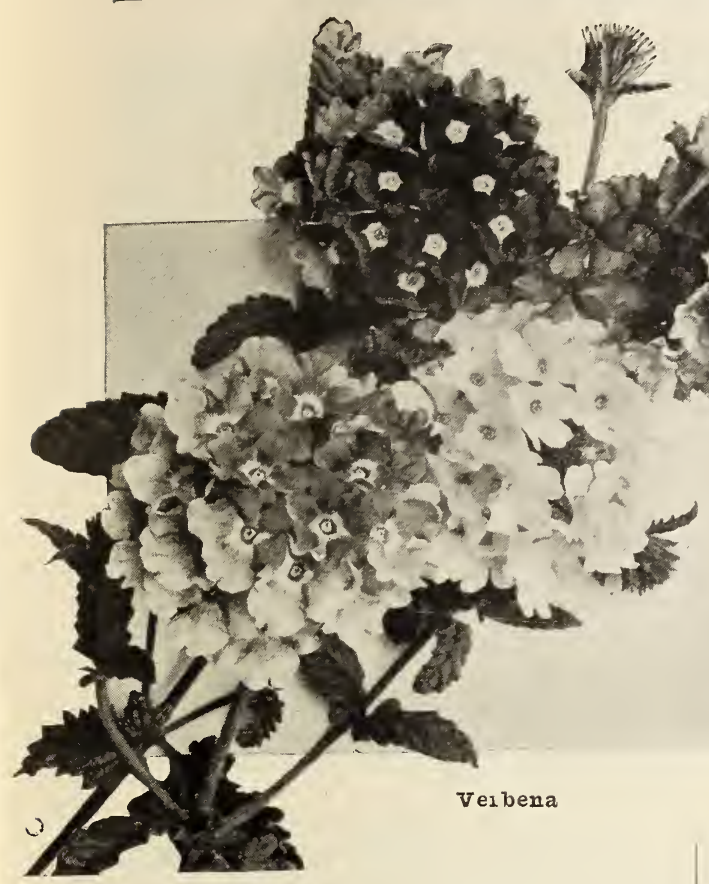

\section{UMBRELLA PLANT}

(Cyprus alternifolius)

This is a plant of the easiest culture, and a large specimen is as handsome as a palm for decoration. It makes an extra fine pot plant, or can be used in baskets or vases with charming effect. $20 \mathrm{c}$ each.

\section{ZEBRA PLANT}

Highly prized decorative plants from South America. Large glossy dark green leaves, variegated and veined with yellow and white, resembling in a manner those of a well marked, broad-leaved Croton. 25c each; 3 for $65 \mathrm{c}$.

\section{SNAKE PLANT (Sanseviera Zeylanica)}

A beautiful plant, especially adapted to house culture during cooler months, and for porches during summer. Leaves are beautiful striped cross-wise with white variegation on a green ground. Withstands dust and drying out without damage, and can be placed in any part of a room and do well. A beautifully decorative plant for vases and baskets. 40c each; 2 for $75 c$.

\section{ROYAL PURPLE PLANT}

Purple foliage and unusually popular on account of its brilliant exquisite coloring, surpassing the finest Coleus or Begonia in the beauty of its leaves. 25c each. Specimen Plants, 50c.

\section{COLEUS}

The Coleus is aptly called the gardener's paint box. We have a superb assortment of the most brilliant colors; fine for pots, bedding; used as bedding plants in parks and lawns everywhere. The following are all bush varieties.

10c each; $\$ 1.00$ per doz.; 30 for $\$ 2.00$.

Trailing Queen Coleus. Center of leaves bright red or pink with a broad border of emerald green; its long branches drooping gracefully in festoons two or three feet long. making a very showy plant for hanging baskets. $15 \mathrm{c}$ each; 2 for $25 \mathrm{c}$.

Christmas Gem Coleus. Leaves immense, 8 to 12 inches long; cannot be excelled as a pot plant, growing 2 to 3 feet high; leaves of bright carmine shading to deep maroon with margins of yellow and green. 25 c each; 3 for 60 c.

Helen Coleus. Leaves very beautiful, medium large, being six to eight inches long; in color the center is a beautiful pink varying to carmine bordered on the edges with a band of pea green mottled with maroon. Makes a beautiful pot plant growing two to three feet high. A new beauty. $25 \mathrm{c}$ each; 3 for $60 \mathrm{c}$.

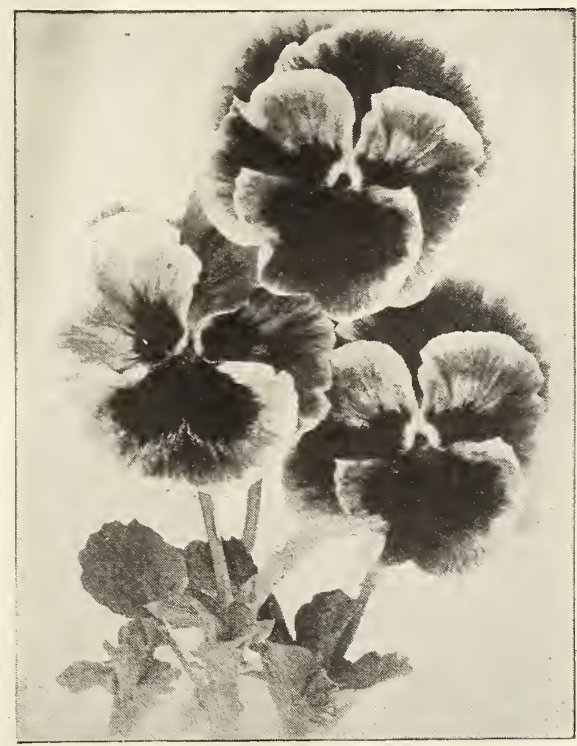

Pansies 


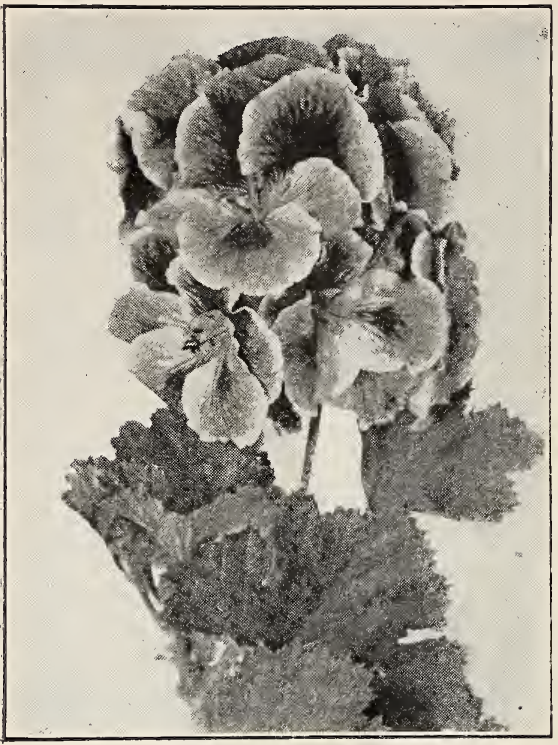

Peiargoniums

\section{WONDER GERANIUM COLLECTION}

One each of the following best varieties for $\$ 1.25$ postpaid. If ordered separate, $25 \mathrm{c}$ each.

S. A. Nutt. Crimson Red. This is the finest of dark crimson Geranium; has now taken the lead as a bedding Geranium.

Madame Landry. A distinct salmon-pink with a slight scarlet shading. This is an exceptional variety, producing enormous trusses and florets on long stems; very hardy.

Beaute Poitevine. Light Pink. Beautiful shade of shrimp pink. This variety is a universal favorite and deserves its reputation.

Ricard. Vermillion. Most beautiful shade of bright vermillion. A grand variety.

Jean Viaud. Rich Pink. This is the best large flowering double pink Geranium; color is the richest deep pink. If you want a large flowering Geranium this is the one to plent.

Buchner. Pure White. The best white Geranium for all uses.

\section{CROTONS}

Splendid plants with variegated foliage both narrow and broad, requiring plenty of moisture. No other genus of decorative plants can furnish such a variety of color. Nothing serves better to give a delirious riot of color than Crotons. They grow well in pots and tubs and give a 'right tropical effect to good advantage. 0c each; Medium, 75c; Large, $\$ 1.00$.

\section{PERFECTION MAMMOTH VERBENA}

Free flowering, half hardy perennial of low spreading growth, usually treated as an annual. They make fine beds and edging. Our Verbenas have been carefully selected and can recommend them as the very best that you can obtain. The trusses nd individual flowers of our Mammoth Verbenas are of brilliant colors, freeb.ooming, and are vigorous growers.

Snow Queen. Pure white flowers, lowgrowing variety; the very best White.

Purple Glory. Richest Purple, and a very heavy grower; very hardy.

Firefly. Scarlet with white center, makirg it very attractive.

Lucifer. Vivid Scarlet, one of the best for porch boxes.

Mayflower. True Pink. The tallest growing of the Verbena family.

Variegated Queen. Pure white border with purple; outer edge of flowers tinged with pink.

True Beauty. Lavender. This is one of the most delicate in colors in the Verbenas. Admired by all. 25c per dozen plants.

\section{VIOLETS}

Princess of $\mathrm{Wa}^{\top} \mathrm{es}$. Violet blue, single scented and a good grower. Fine for edging. $5 \mathrm{c}$ each; $50 \mathrm{c}$ per doz.

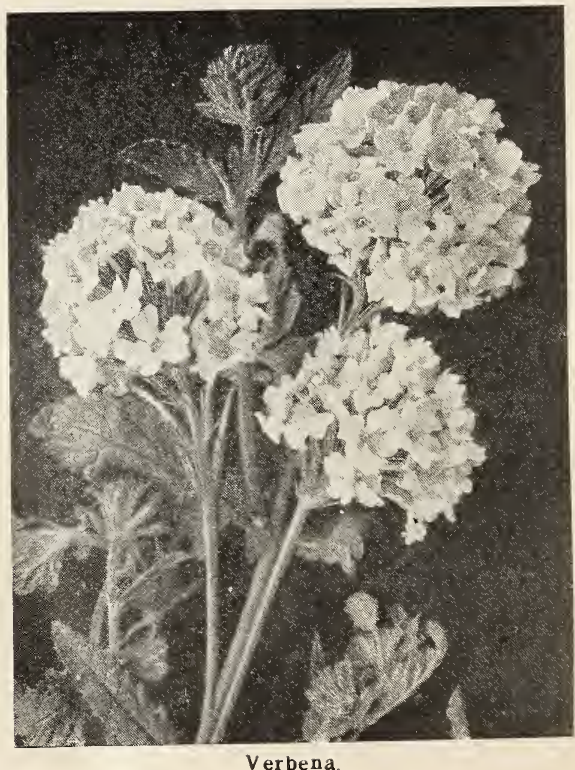




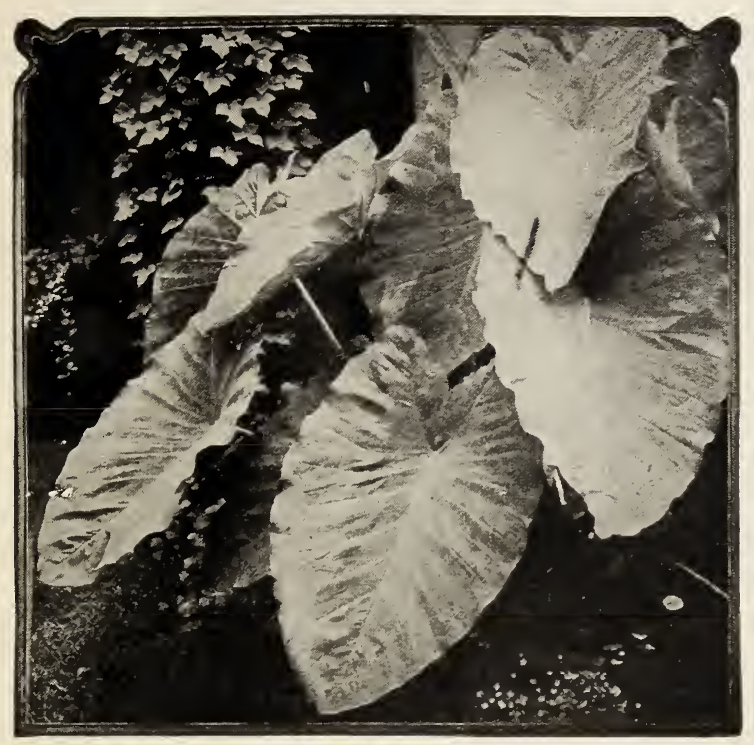

caladiums

Easter Greeting. Earliest and very large fiery red florets; only kind that blooms in beds as well as in pots all summer.

Gardener's Joy. Ground' color of apple-blossom pink, the two upper petals having blotches of carbon-brown.

Lucy Becker. This good novelty is a sport from Easter Greeting, and like it in every way except color which is rosy pink; even a better bloomer. $25 \mathrm{c}$ each; 3 for $75 \mathrm{c}$.

\section{PETUNIAS}

A splendid assortment made up of California Giants and Ruffled Petunias in a wonderful assortment of colors and forms. These are the most beautiful of all the Petunias. Fine for porch boxes. 10c each; $\$ 1.00$ per doz.

\section{TRAILING VINCA (Periwinkle)}

\section{PANSIES}

One of the most satisfactory plants. We have the choicest large flowering sort in an assortment of colors unsurpassed.

There is no flower more admired than the Pansy. Our assortment of colors embraces Striped, Spotted, Bordered, Fringed, Ruffled and Scalloped, in Rainbow colors, with rich velvety texture. 6 for $25 \mathrm{c}$; 12 for $50 \mathrm{c}$; 100 for $\$ 3.50$, postpaid.

\section{SALVIA}

No plant is more popular in the South for bedding, from late summer until late fall; until frost it is a mass of bloom of fiery red unequalled by any other flower on our list. $10 \mathrm{c}$ each; $\$ 1.00$ per dozen.

\section{SHASTA DAISY}

One of the marvelous introductions in the flower line. Very hardy perennial with large free blooming flowers that last two weeks after being cut. $10 \mathrm{c}$ each; 3 for $25 \mathrm{c}$.

\section{PELARGONIUMS}

Lady Washington Geraniums. One of the grandest of all flowering plants; does not resemble the common Geranium in foliage or in bloom; more beautiful in every way. The Lady Washington Geranium is the handsomest of all flowers; once seen never forgotten. We have best varieties for the South in named varieties :

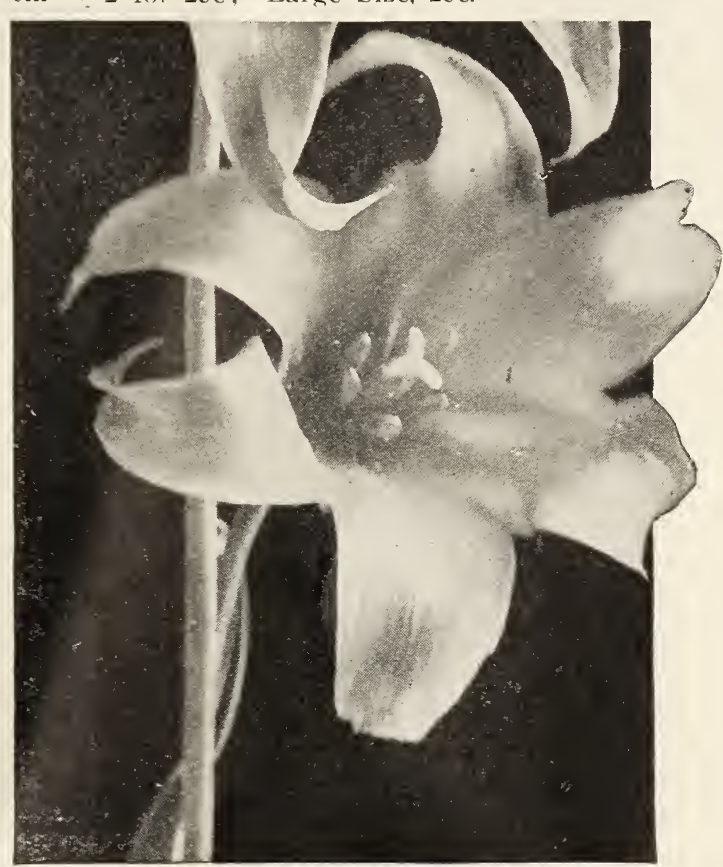

Hemerocalis 


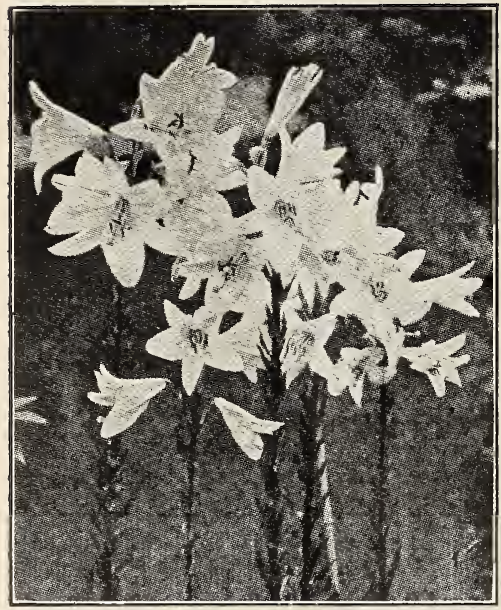

Easter Iily.

\section{WANDERING JEW}

This fine trailing plant is very popular for baskets and window boxes. In three colors-Green, Red Striped, and White Variegated. 10 c each; 3 for 25 c.

\section{PORCH BOXES, ETC.}

English Ivy. The well known English Ivy. An excellent covering for walls and tree trunks. $25 \mathrm{c}$ each; 3 for $65 \mathrm{c}$.

\section{PALMS AND CYCADS}

Cycas revolta. A palm-like Cycad reaching a height of 3 to 4 feet, with a handsome crown of deep green.leaves curved outward from the center; very hardy. Medium size, $75 \mathrm{c}$; Large size, $\$ 1.00$.

Phoenix canariensis. A stately Palm with large trunk and large pinnate, gracefully curved leaves; a very rapid grower; very hardy and one of the best for outdoor planting in the Gulf Coast country. 3 -inch pots, $40 \mathrm{c}$ each; 10 for $\$ 3.50$. Large size plants, $\$ 1.50$.

Washingtonia Robusta. A splendid Palm with dark green fanshaped leaves; hardy, well adapted to the country bordering on the Gulf of Mexico; it is a rapid grower and is being widely planted. One of the finest for ltndscape work. Reaches a height of 60 feet. Prices in pots, 35c each; 10 for $\$ 3.00$.

YUCCA (Soft Leaf)

A conspicuous plant with soft evergreen foliage. The large cluster of creamy white flowers produced in Summer makes a fine effect. Excellent for massing. 10c each; 3 for $25 \mathrm{c}$.

\section{CANNAS}

New beauties dominate the Canna world. Where, except in these wonderful Cannas, will you find such pure colors? Our large fields of Cannas in their wonderful colors brought us hundreds of visitors to see them this season. It will well repay you to drive over in the summer time to see our Canna fields.

Prices on Cannas are postpaid.

Apricot. $4 \mathrm{ft}$. Flowers have marvelous durability; unlike most Cannas, this rich Apricot variety is suitable for cutting. One 2 to 3 eye division, $20 \mathrm{c}$; 6 for $\$ 1.00$.

American Beauty. $5 \mathrm{ft}$. Richest colored Canna we know, oriental carmine; large flowers; green foliage. One 2 to 3 eye division, $30 \mathrm{c} ; 6$ for $\$ 1.50$.

Florence Hall. Beautiful green foliage and flowers on stems well above foliage; in color delicate shell pink, so many saying it looks like an Orchid. One of the very best. Grows about four feet high. One 2 to 3 eye division, 30c 6 for $\$ 1.50$.

King Humbert. $5 \mathrm{ft}$. Fiery Red. Most popular and satisfactory Canna; large compact flower heads with large ruffled or orchid wide open

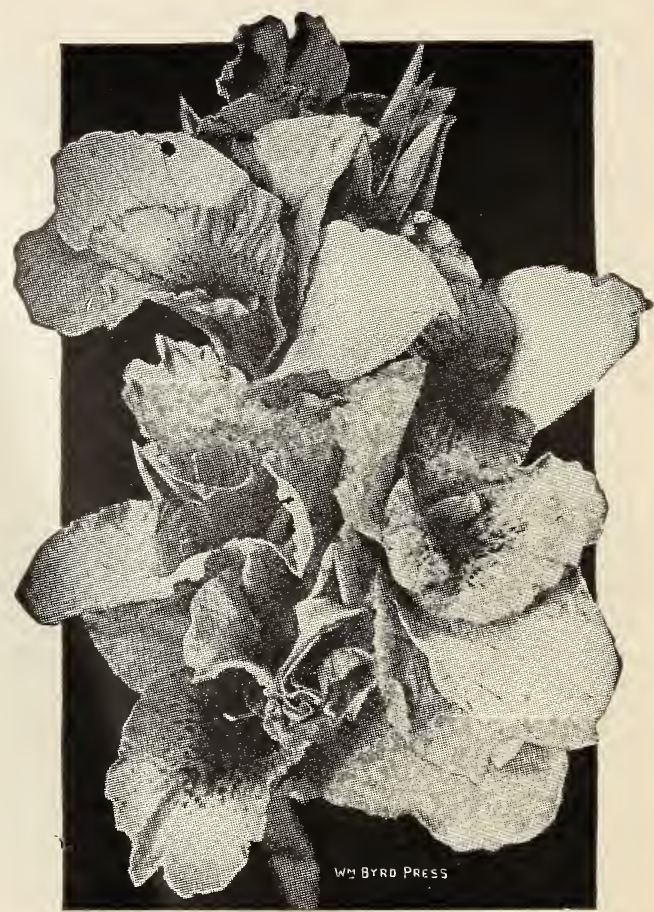

King Humbert Lai- 
blooms. Grows about 5 feet high. One 2 to 3 eye division, 25 ; 6 for 50 c; 12 for $\$ 1.00$.

Mrs. Alf Conard. $4 \mathrm{ft}$. Salmon Pink. Stocky green foliage, surmounted by extra large trusses of 6 to 18 large flowers with large broad reflexed petals open at a time. Color extremely beautiful shade of very deep flesh pink to salmon pink; deeper in throat. Visitors were very enthusiastic about it. Grows about 4 feet high. One 2 to 3 eye division, $15 \mathrm{c}$; 2 for $25 \mathrm{c}$; 6 for 75 c.

The President. $4 \mathrm{ft}$. Glowing Scarlet. Green foliage; extra large trusses on strong shafts well above foliage. Compact heads of gigantic bloom. The President is superior to any other red Canna with green foliage. Grows about 4 feet high. Two 2 to 3 eye divisions, $25 \mathrm{c}$; 6 for $55 \mathrm{c}$; 12 for $\$ 1.00$.

Flambeau. $5 \mathrm{ft}$. Orange striped with yellow. This is a Canna that every one who visits our flower gardens always likes -a bouquet in itself. Grows about 5 feet high. One 2 to 3 eye division, $25 \mathrm{c}$; 6 for $50 \mathrm{c} ; 12$ for $\$ 1.00$.

Eureka. $3 \mathrm{r} / 2 \mathrm{ft}$. White. Foliage green, heavy, strong, low growth with large compact heads of large blooms. Grows about $31 / 2$ feet high. One 2 to 3 eye division, $35 \mathrm{c} ; 6$ for $\$ 1.00 ; 12$ for $\$ 1.75$.

\section{AMARYLLIS (Johnsoni)}

Sometimes called St. Joseph Lily. The color is a fine crimson scarlet with a broad white strip down the center of each petal. Very fine for pot culture. Large Blooming Bulbs, 35c each; 6 for $\$ 2.00$.

\section{CALADIUM}

Fancy-Leaved Bulbs. These come in all the colors of the rainbow, making fine plants for separate pots, window boxes or vases. As Fancy-Leaved Caladiums are very tender to cold, we advise you not to plant before March, but do suggest that you send your order early so as not to be disappointed. 20c each; $\$ 2.15$ per dozen.

Elephant Ear Caladium. Do not con-

\section{SPECIAL OFFER FOR CANNA BEDS}

Gorgeous Cannas, all colors, mixed, large flowering, the finest bedding plants, and with Montbretias for border to make a six-foot bed.

Price, $\$ 5.00$. fuse this variety with the Fancy-Leaved variety. It grows 4 to 5 feet tall and has immense leaves shaped like an elephant's ear, hence the name. Very decorative and fine in single plantings or for groups. Large Bulbs, 15c each; 2 for 25c; 6 for $70 c$.

\section{CRINUMS}

Sometimes called the Southern Lily. The sword-shaped leaves form a' rosette from which very large fragrant flowers appear in immense clusters. Fine for planting along fences and center of beds.

Kirki. Soft delicate pink with a light red stripe down through each petal.

Capense. White striped, rose color on the back of each petal.

Capense alba. White and very fragrant.

Prices on the three varieties-20c each; 6 for $\$ 1.00$.

\section{HEMEROCALLIS}

Day Lily. Fine for border plants with large lily-shaped flowers borne on long stems. Very profuse bloomer. Fine for planting in front of shrubs.

Single Yellow. Double orange colors.

Prices on both-8c each; 6 for $40 c$; 12 for $75 c$.

\section{EASTER LILY}

Sometimes called Creole Lily. This lily is the best for outdoor planting in the South. The flowers are of purest white. No flower garden is complete without this Queen of the Lily family. 20c each; 6 for $\$ 1.00 ; 12$ for $\$ 2.25$.

\section{BUTTERFLY LILIES}

A straight upright growing plant with large clusters of fragrant snow-white flowers. Should be planted in good rich soil; requires plenty of water. $10 \mathrm{c}$ each; 6 for $50 \mathrm{c}$; 12 for $90 \mathrm{c}$.

\section{TUBEROSES}

Mexican Everblooming. Single pure white flowers, excellent for cut flowers; easily grown; very fragrant. $5 \mathrm{c}$ each; 6 for $25 \mathrm{c} ; 12$ for $40 \mathrm{c}$.

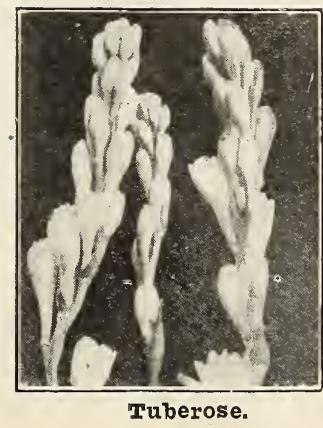




\section{ZEPHYRANTHES (Fairy Lilies)}

Lovely small plants with long narrow leaves and pretty lily-like flowers placed single on each stem.

Rosea. Very large and beautiful flowers of a clear rose color. $5 \mathrm{c}$ each; 6 for $25 \mathrm{c}$; 12 for $45 c$.

Candidum. Pure white flowers; fine for edging. 6 for $15 \mathrm{c}$; 12 for $25 \mathrm{c}$.

\section{MONTBRETIA}

Gold with a throat of burnt orange; a very free-flowering plant that succeeds admirably in the garden, producing its long many flowered panicles of gold orange flowers from July until frost. 6 for $25 \mathrm{c}$; 12 for $40 \mathrm{c} ; 100$ for $\$ 3.00$.

\section{REGALE LILY}

A new variety from China. It is absolutely hardy and is excellent for forcing. It has been predicted that this will become the Easter Lily of the future; being so hardy may be grown at home. The flowers are white slightly suffused with pink, with a beautiful shade of canary yellow at the center. It is delightfully perfumed, reminding one of the Jasmine, lacking the heavy oppressive odor of most lilies. Flowering Bulbs, 50c; Large size, 75c.

\section{WHITE SPIDER LILY (Western)}

This grand Lily forms large imposing clumps that are a mass of clustered heads of pure white fragrant flowers. 20c each; 6 for $\$ 1.00$.

\section{WINTER FLOWERING BULBS}

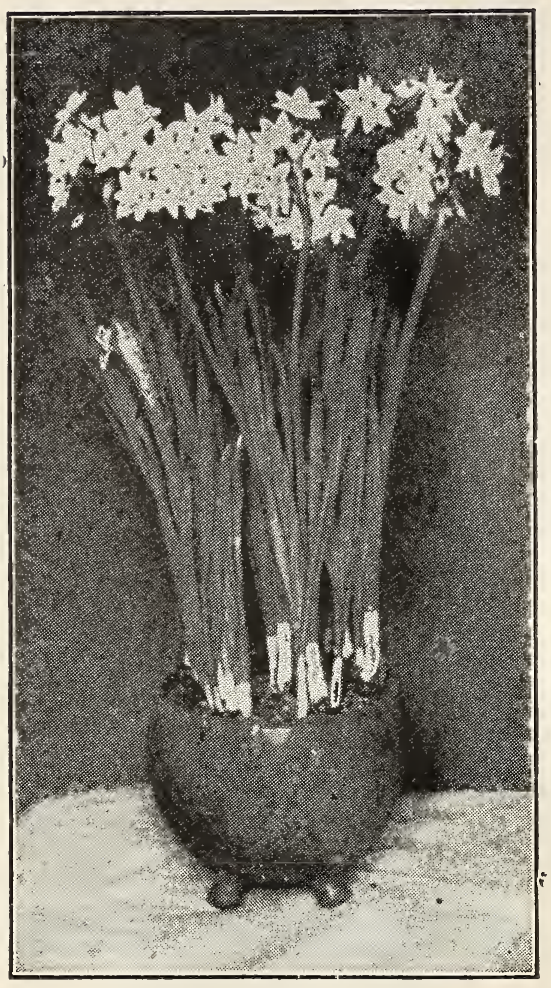

\section{Must Be Planted in Fall}

\section{NARCISSUS}

Paper White Grandiflora. One of the most satisfactory of all Narcissus. Pure white and one that does well in pebbles and water. $10 \mathrm{c}$ each; 6 for $45 \mathrm{c} ; 12,75 \mathrm{c}$.

Chinese Sacred. This bulb is a native of China. It is a strong grower, producing big clusters of pure white flowers with yellow cups. This is one of the best. Used in pebbles and water.

Groot Vorst or Staten General. One of the strongest growing of the Narcissus family. Large flowers of creamy tint with a deep yellow cup borne on long stiff stem. A great favorite. $10 \mathrm{c}$ each; 6 for $45 \mathrm{c}$; 12 for $75 \mathrm{c}$.

\section{NARCISSUS IN MIXTURE}

You receive all the different varieties and colors making a splendid mixture. Will add life and beauty to your spring garden. $5 \mathrm{c}$ each; 6 for $25 \mathrm{c}$; 12 for $45 \mathrm{c}$.

\begin{tabular}{|c|}
\hline Perfection Mixture \\
GLADIOLUS COLLECTION \\
Fine Blooming Size Bulbs \\
35c per dozen; 3 dozen for $\$ 1.00$. \\
\hline
\end{tabular}

We grow all our own Bulbs, and you are assured of getting the colors and varieties you order, when you order from the Perfection Nurseries 


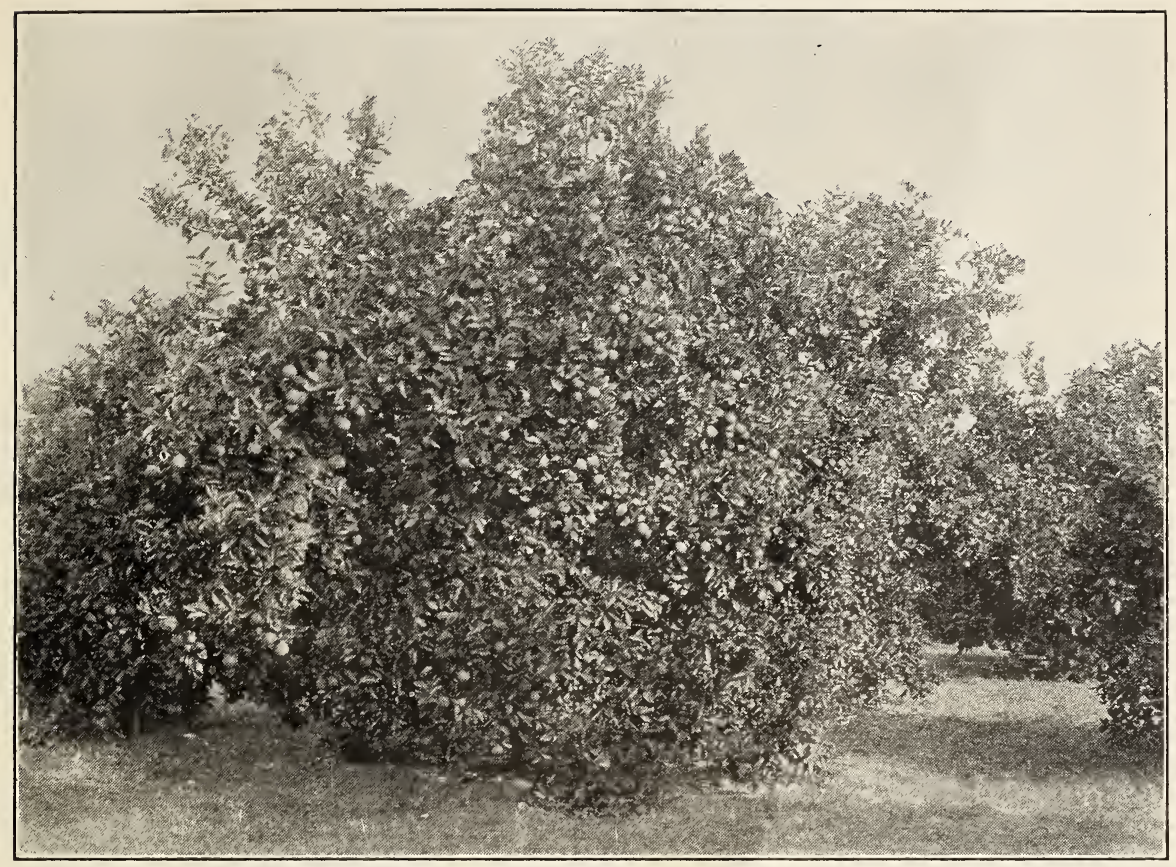

Satsuma Orange Grove

\section{Citrus Fruits}

\section{SATSUMA ORANGES}

In planning your Satsuma grove and looking into the future, do so with the same idea in mind as we did when we secured the bud-wood for our Satsuma Trees. We went into the individual record of each grove tree from which we cut the bud-wood. They had to be in good condition and show a fine record for many years past producing heavy crops of good fruit. Every grove has its number of drones and weak trees caused by poor selection of bud-wood. In buying your trees see the individual trees from which the bud-wood was cut, examine their past individual records. If you don't do so you are gambling with drones and weak trees. We invite you to examine the records of our trees so we can show you we are building for better Satsuma Groves. This last season we sold all but 2 per cent of our entire stock, attesting to the fact that the Old Growers are planting Record Trees. We have no old stock that we have been carrying along for years, but nice young well grown trees. Make your future grove a planting of Perfection Brand Individual Tree Record Trees, and have no regrets later on.

Our Nurseries are not infested with Nut Grass or other noxious weeds.

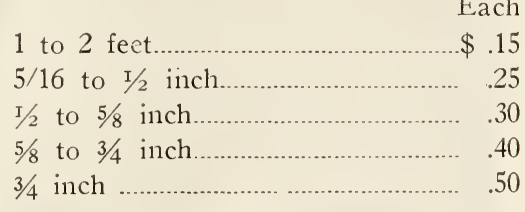

Write for prices on larger quantities.

Satsumas are one of the best fruits to plant dlong the gulf coast, they standing the winds, and give quick return on the investment. In the young orchards there can be many kinds of crops raised during the first and second seasons of their planting; by that time they have attained a size where they are large enough to use all the ground and give some return in fruit. We are always glad to assist any one contemplating planting a grove. 


\section{TANGELO}

A cross between the Tangerine and the $\mathrm{Po}$ melo; has a very desirable flavor; should be included in all home plantings.

Medium size, $50 \mathrm{c}$.

Large size, $75 \mathrm{c}$.

\section{GRAPEFRUIT}

Duncan Variety. No breakfast table ought to be without Grapefruit. We have an extra fine block of trees for this season's trade.

Each

1 to 2 feet.........\$.40 $5 / 16$ to $\mathrm{I} / 2$ inch.. .50 $5 / 8$ to $3 / 4$ inch...... .60 $3 / 4$ inch

.75

\section{KUMQUATS}

\section{Meiwa and Nagami Varieties}

Medium size, each. Large size, each. $\$ .50$

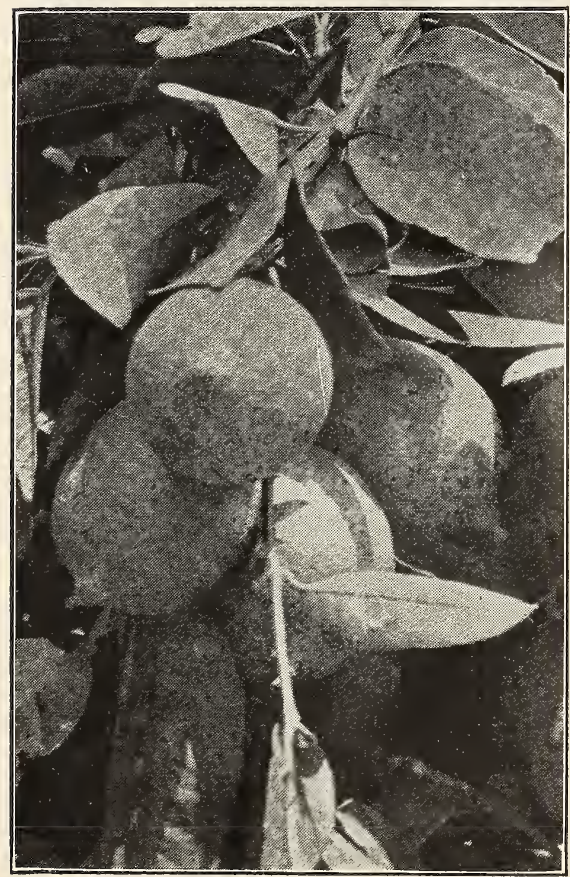

Iemons

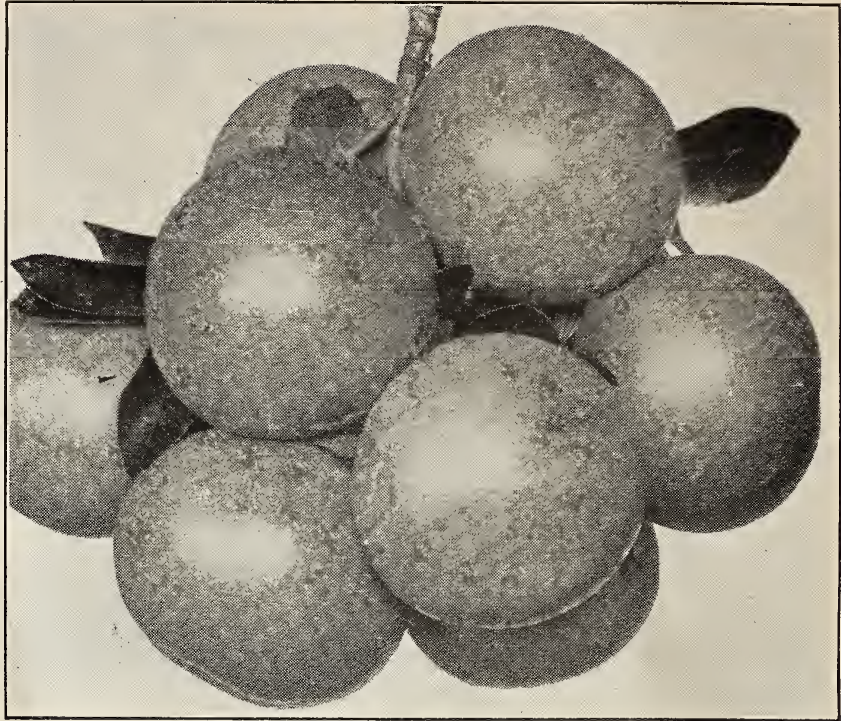

A Bunch of Grapefiust

\section{LIMEQUATS}

This is one citrus fruit that is gaining favor every year, the fruit taking the place of the lemon.

Large size, each. $\$ .75$

\section{PONDEROSA LEMON}

This tree is noted for its wonderful foliage and the large size of its fruit.

Large size, each. $\$ .75$

\section{RUBY ORANGE}

A valuable variety, the fruit being unsurpassed in quality of its kind; skin thin, very tough, pulp melting, rich, juicy, and of exquisite flavor. The tree is a good grower, dense foliage, thornless, and a regular, prolific bearer.

Medium size, each $\$ .50$

Large size, each. .60

Specimen, each .75

Many times you are unable to decide just what varieties of fruit or nuts that you should plant for best results, and for that reason postpone from year to year the planting of these very valuable trees.

If in doubt we will be glad to give you any advice our years of experience wil! enable us to render you. 


\section{Fruits and Berries}

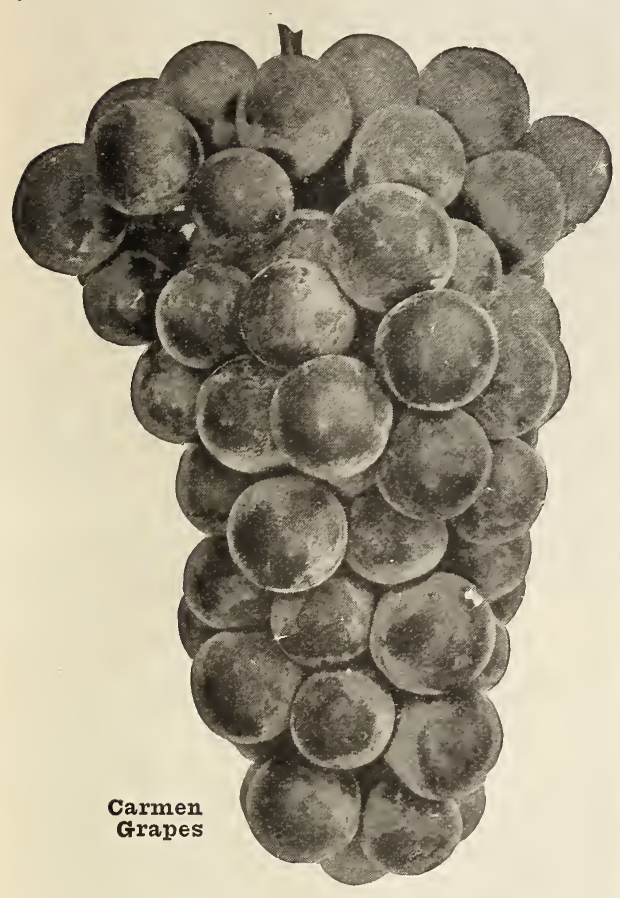

APPLES

Varieties: Red June, Ben Davis, Winesap, Early Transparent.

2 to $3 \mathrm{ft}$., each.......... $\$ .30$

3 to $4 \mathrm{ft}$., each. .35

\section{PEARS}

Pears are so easily grown that every home should have enough planted to supply their own table. We have a good grade of Pears this year, and the Douglas is a very fine eating pear. It is a very early and heavy bearer.

The Pineapple (Chinese sand) takes the place of the Apple. We have two new Pears we will place on the market this coming year that will not blight, and is a large, good eating pear.

Varieties: Le Conte, Pineapple, Garber, Douglas, and Kieffer.

\begin{tabular}{|c|c|}
\hline E & Each. \\
\hline & .50 \\
\hline 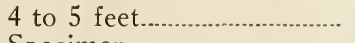 & .65 \\
\hline
\end{tabular}

\section{PLUMS}

Varieties: Excelsior and Terrell.

These are two of the very best Plums for the South, and should be considered in the small fruit plantings. We have an extra fine stock.

\begin{tabular}{lll}
2 to 3 feet & Each. \\
3 to 4 feet & .35 \\
4 to 6 feet & .50 \\
Specimen size &.$\ldots \ldots \ldots \ldots$ \\
\hline
\end{tabular}

\section{PEACHES}

We have Peaches budded on peach root and on plum root. This plum is not the variety that suckers and makes you trouble later on.

Varieties: Belle of Georgia, Carman, Hiley, and Elberta.

Each. Per 10.

2 to 3 feet........................ \$ $25 \$ 2.00$

3 to 4 feet................................ 35

\section{Prices (Budded on Plum Stock)}

2 to 3 feet. Each.

3 to 4 feet.............................................. .65

\section{COMPASS CHERRIES}

A cross between the Sand Cherry and the Plum. Fruit about as large as the ordinary Cherry; very bright red; valuable because of its sure heavy cropping qualities. Used for preserving.

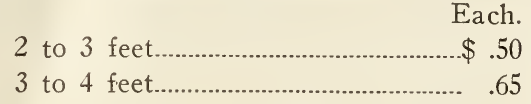

\section{PERSIMMONS}

Varieties best for this section are the Tane-Nashi for early fruit, and the Honey or Triumph for late fruit. The Tamopan is also a good variety.

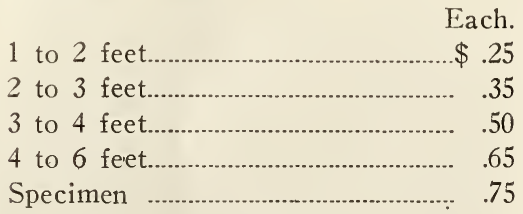

\section{POMEGRANATES}

Pomegranates are hardy in the Gulf section of the country and in the central Southern States. It is a rapid grower; fruits early, from which a very good drink is made. $25 \mathrm{c}$ each; 3 for $65 \mathrm{c}$. 


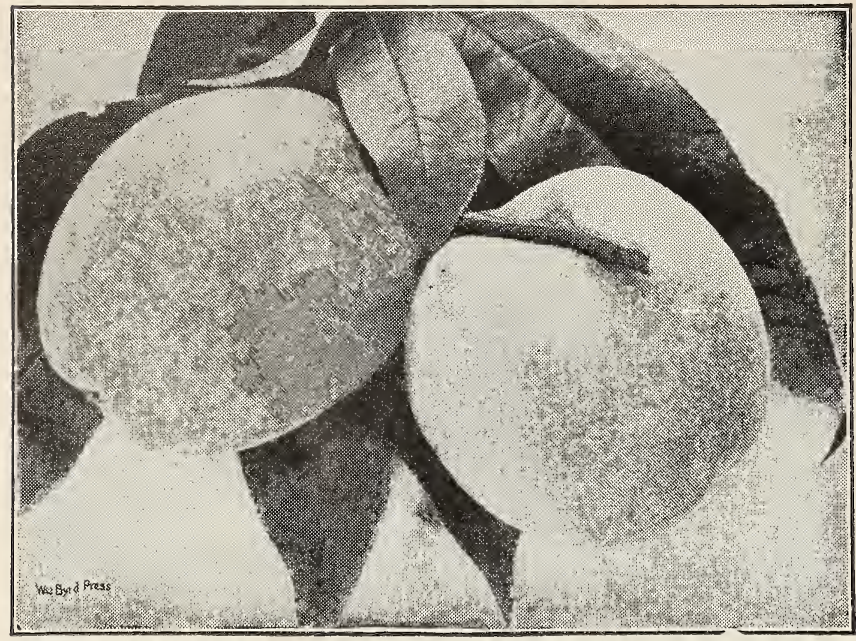

DEWBERRIES

Y o u g Dewberry. This is a fruit that is extra large and a good shipper. Berries are as large as a quarter, flavored with a tinge of Raspberry. Very prolific. Each $30 \mathrm{c} ; 2$ for $50 \mathrm{c} ; \$ 10.00$ per $100 ; \$ 45.00$ per 1,000 .

All Shrubs in this Catalog priced $25 \mathrm{c}$ each, 3 for $65 \mathrm{c}$, we do not ship less than $\$ 1.00$ owing to packing charges.

\section{FLOWERING POMEGRANATE}

These shrubs are among the most satisfactory for general planting. Beautiful flowers produced all summer, in a rich tone of red. $25 \mathrm{c}$ each; 3 for $65 \mathrm{c}$; Specimen plants, $40 \mathrm{c}$.

\section{GRAPES}

The planting of Grapes here in the Southland has long been neglected. Every home should have a selected planting of Grapes-both of the commercial varieties, and those for the home use. The Grape is one of our fruits that bring returns on the investment in two and three years under proper care.

Varieties: Carman, Agawan, Worden, Ives, Niagara, Scuppernong.

Prices: $25 \mathrm{c}$ each; $\$ 2.00$ per $10 ; \$ 15.00$ per 100 ; extra heavy plants, $50 \mathrm{c}$ each.

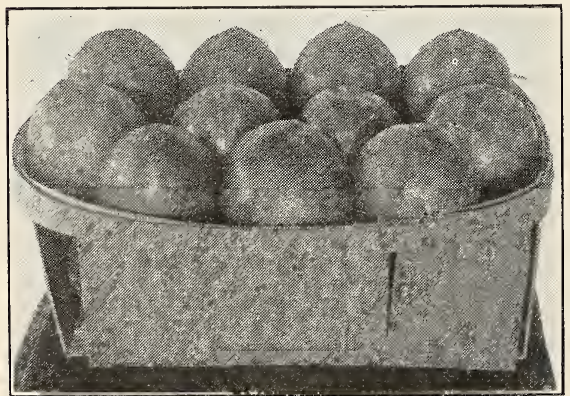

Tane-Nashi Persimmons

\section{FIGS}

Varieties: Brown Turkey, Lemon, Celeste, and Brunswick.

Each. Per 10.

1 to 2 feet. $\$ .20$

$\$ 1.50$

2 to 3 feet.

3 to 4 feet.

\section{Nuts}

\section{PECANS}

Every one in the South are realizing the value of the Pecan more each year; more

and more are being planted in orchards and for shade around the home. You can farm between the trees until they get to where they are a paying proposition themselves, or you may interplant with other. fruits.

\section{Prices (Budded and Grafted)}

Each. Ten. Per 100.

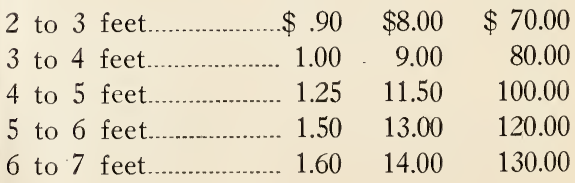

BLACK WALNUT

2 to 3 feet. $50 \mathrm{c}$ each 
WE GUARANTEE all stocks sent out to be well rooted, well grown, true to ame, properly packed, and shipped according to instructions. Our liability under the foregoing guaranty is limited in amount to the original price received.

\section{PERFECTION NURSERIES}

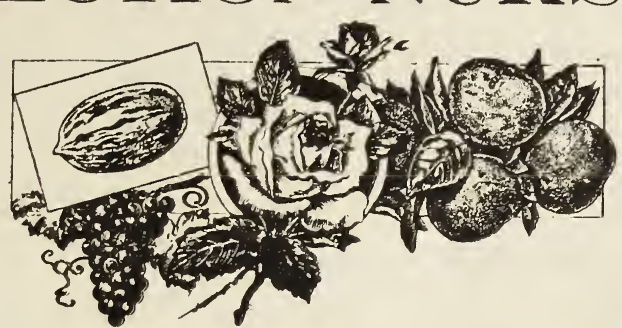

Foley, Ala.

WHEN BETTER NURSERY STOCK IS GROWN, WE WILL GROW I'!

Please forward.

On or about

Express Office.

Freight Office.

Name.

Post Office

County .

State.

\section{Amount Enclosed}

Post Office Order... \$........

Express Money Order $\$ \ldots . . . .$.

Bank Draft

$\$ \ldots \ldots \ldots$

Check

$\$$.

1/DOR $A \mathrm{NT}$ Be sure to write name and address, also shipping directions $11 \mathrm{~L}$ III very plainly. Please state if we may substitute other sizes or varieties in case those ordered are exhausted, yes....... or no...... if undecided as to best varieties, we will select same accrding to our best judgement, if so requested Please write any other instructions on separate sheet.

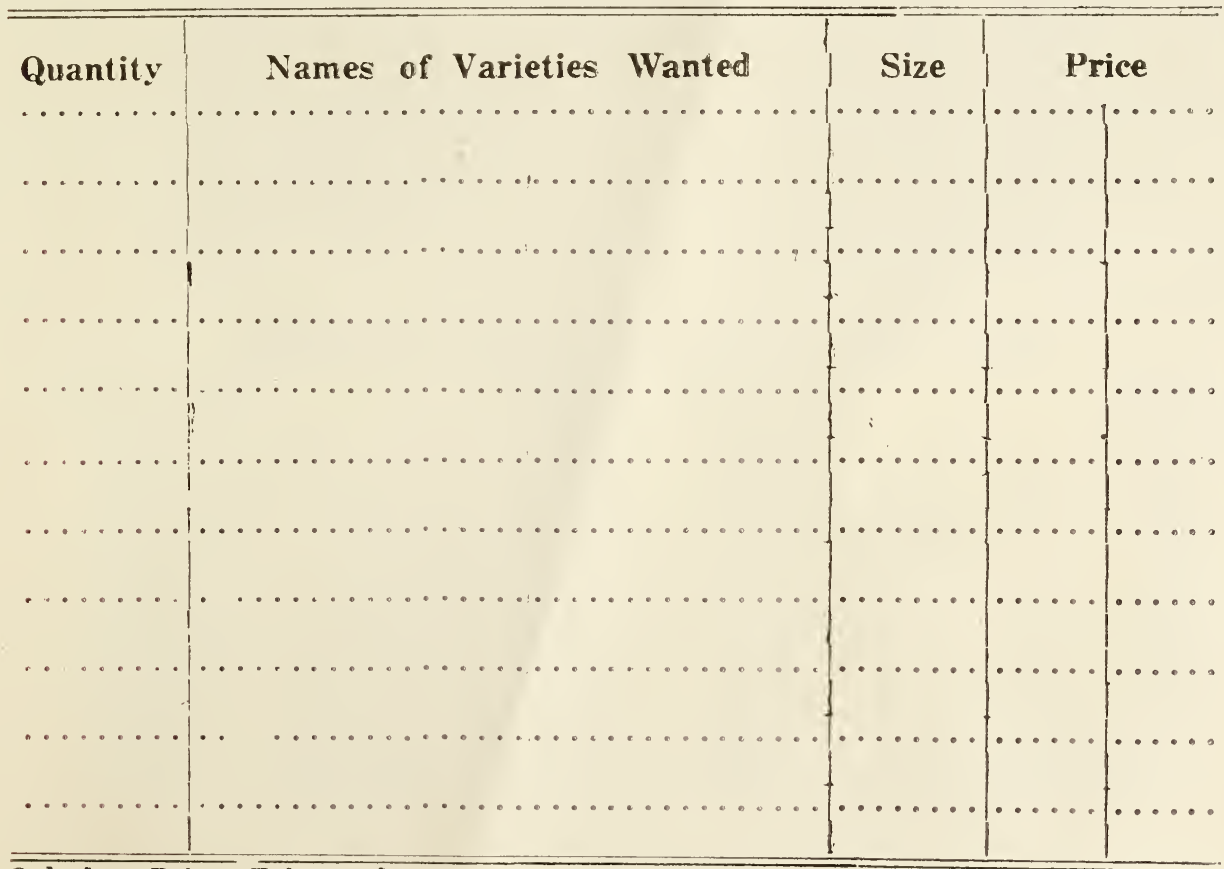

Onlooker Print, Foley, Ala. 


\section{Plant Pep Makes 'Em Grow}

A wonderful plant food-Plant Pep is a complete, quick-acting fertilizer, containing in concentrated form the plant foods and soil sweetness used by professional gardeners and florists. It is clean, odorless and safe to use. Increases foliage, enhances the color. 15 c per package (20c, postpaid).

\section{Red Hanging Baskets}

These Hanging Baskets are equipped with a round wire band which fits under the shoulder, and to which are attached the wires for hanging the basket. By so supporting the basket we have been able to do away with the holes in the side near the top, making it possible to water the plant without the water running out through the holes, discoloring the pot, and soiling the floor. Each $75 \mathrm{c}$.

\section{Satsuma [Owari] Buds}

\section{Prices:}

1 to 5 thcusand, per thousand.........\$10.00 | 5 to 10 thousand, per thousand..........\$9.00 10,000 and more, per thousand.................\$8.00

\section{Perfection Brand Budding Cloth}

Size of sheet, approximate, 36 by 36 inches.

Price: Per sheet.. $80 \mathrm{c}$

\section{PROPER DISTANCES FOR PLANTING}

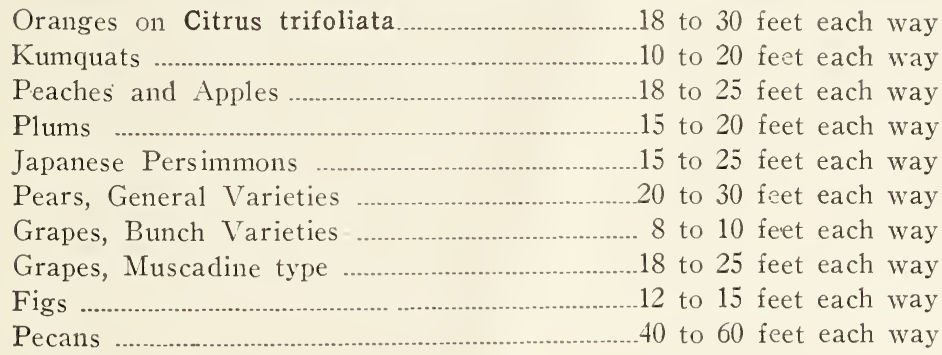

\section{NUMBER OF TREES OR PLANTS TO THE ACRE}

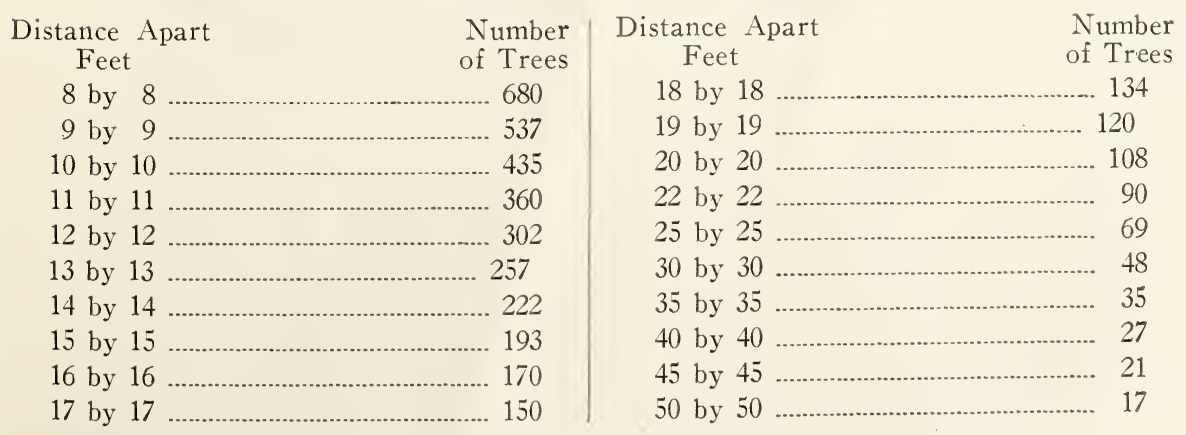


